\title{
The New Immigration Federalism
}

\author{
STELla BuRCH Elias*
}

The Supreme Court's recent rulings in Arizona v. United States (2012) and Chamber of Commerce v. Whiting (2011) mark a watershed in immigration law and doctrine. Because the Supreme Court held that state and local indirect enforcement measures are no longer permissible, some scholars have argued that this signals the end of state and local engagement in immigration regulation. I believe, to the contrary, that Arizona and Whiting portend a new direction for immigration federalism, with increased emphasis on states' and localities' opportunities to promulgate immigrant-inclusionary measures. This "new immigration federalism" encompasses dynamic and interactive multigovernmental rulemaking pertaining to immigrants and immigration, including rulemaking intended to foster immigrant inclusion. By analyzing recent initiatives for immigration law reform, including Senate Bill 744, the "Border Security, Economic Opportunity, and Immigration Modernization Act," the Obama Administration's Deferred Action for Childhood Arrivals Program, the "Illegal Immigrant Relief Act" lawsuits in Pennsylvania and Texas, the noncooperation ("sanctuary") ordinances passed in California and Illinois, numerous state "DREAM Act" initiatives for immigration youth, current legal challenges to immigration enforcement statutes in Alabama, Arizona, Utah, Indiana, Georgia, and South Carolina, and numerous immigrant-inclusionary measures enacted by state legislatures since the Court's Arizona opinion, this Article proposes that such developments are best understood within the coherent framework of the new immigration federalism. This new immigration federalism, grounded in immigrant-inclusionary rulemaking, has the potential to inform, complement, and occasionally contradict federal efforts at comprehensive immigration reform.

\section{TABLE OF CONTENTS}

I. INTRODUCTION

II. (RE)DEFINING "IMMIGRATION FEDERALISM".

${ }^{*}$ Associate Professor of Law, University of Iowa College of Law. J.D. 2009, Yale Law School; M.A. 2006, Oxford University; B.A. 1998, Oxford University. I am very grateful to Dane Lund, Jordan Moody, and Kate Ono Rahel for excellent research assistance and to the editors of the Ohio State Law Journal for their terrific editorial work. Many thanks to Eric Andersen, Albertina Antognini, David Barron, Yochai Benkler, Andrew Bradt, Rachel Brewster, Steven Burton, William G. Buss, Glenn Cohen, Michael Coenen, Tom Donnelly, Ingrid Eagly, Bram Elias, Heather Gerken, Jill Goldenziel, Paul Gowder, Pratheepan Gulasekaram, Herbert Hovenkamp, Emily Hughes, Howell Jackson, Vicki Jackson, Kit Johnson, Nancy L. Jones, Michael Klarman, Sheldon Kurtz, Kevin Lapp, John Manning, Lindsay Nash, Gerald Neuman, Todd Pettys, Shruti Rana, Jason Rantanen, John Reitz, Judith Resnik, L. Song Richardson, David Rubenstein, Ben Sachs, Peter Schuck, Barbara Schwartz, Jed Shugerman, Reva Siegel, Maya Steinitz, Juliet Stumpf, Susannah Tobin, Arivee Vargas, James Whitman, Michael Wishnie, John Witt, Mark Wu, and the participants in the Harvard Law School Climenko Workshop and the Yale Law Teaching Workshop for their thoughtful comments on earlier versions of this Article. 
III. The NEW IMMIgRATION PREEMPTION DOCTRINE............................711

A. Arizona v. United States and Immigration Preemption ......... 712

B. Chamber of Commerce v. Whiting and Alienage Laws ......... 719

IV. THE NEW IMMIGRATION FEDERALISM AND IMMIGRANT

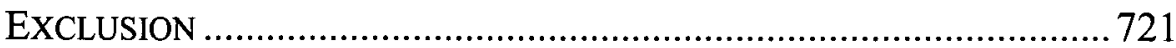

A. Expressly Delegated Direct Enforcement .............................722

B. Independent Direct Enforcement ...........................................726

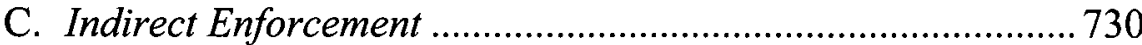

V. THE NEW IMMIGRATION FEDERALISM AND IMMIGRANT

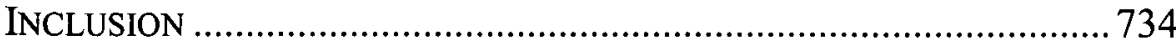

A. Comprehensive Sanctuary Ordinances ................................. 735

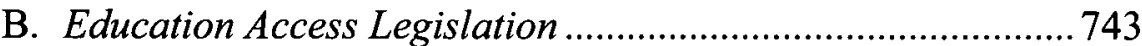

VI. CONCLUSION: THE CHALLENGES AND OPPORTUNITIES OF THE NEW IMMIGRATION FEDERALISM.................................................... 748

The Government of the United States has broad, undoubted power over the subject of immigration and the status of aliens. ${ }^{1}$

[OJur federal system in general-necessarily entails the prospect of some departure from homogeneity. ${ }^{2}$

\section{INTRODUCTION}

During the 2011 and 2012 legislative sessions, comprehensive immigration reform was once again a topic of vibrant debate and speculation in Congress, in the media, and in the legal academy. On June 27, 2013, the Senate passed S. 744, the "Border Security, Economic Opportunity, and Immigration Modernization Act." 3 Speculation abounded-and indeed continues to abound-as to what action, if any, the House of Representatives might take. But, as federal lawmakers and commentators argued the relative merits of different proposed solutions to cut visa backlogs, attract immigrants with skills in science and technology, and address the challenges posed by approximately 11.2 million undocumented migrants, ${ }^{4}$ some of the most important stakeholders - the governments of the fifty states-were unusually silent. This was particularly noteworthy, because until the summer of 2012, those very state governments were often at the forefront of efforts to influence the reform of immigration law and policy; in 2010, for example, 346 separate bills pertaining

${ }^{1}$ Arizona v. United States, 132 S. Ct. 2492, 2498 (2012).

${ }^{2}$ Chamber of Commerce v. Whiting, 131 S. Ct. 1968, 1980 (2011).

${ }^{3}$ Border Security, Economic Opportunity, and Immigration Modernization Act, S. 744, 113th Cong. (2013).

4 JefFrey S. Passel \& D'Vera Cohn, Pew Research Ctr., Unauthorized IMMIGRANT POPULATION: NATIONAL AND STATE TRENDS, 2010, at 9 (Feb. 1, 2011), available at http://www.pewhispanic.org/files/reports/133.pdf. 
to immigration and alienage were passed by state legislatures. ${ }^{5}$ The catalyst for the change in states' immigration-related rulemaking was the United States Supreme Court's June 25, 2012 decision in Arizona v. United States, ${ }^{6}$ which reasserted the federal government's primacy in the immigration arena and clarified the boundaries of federal, state, and local rulemaking pertaining to immigration enforcement and immigration-related criminal sanctions.

In the wake of the Arizona ruling, a number of states suspended immigration enforcement operations and ceased to promulgate antiunauthorized-immigrant laws. At the same time, immigration law scholars and commentators-some of whom had previously argued that it would be "conceptually unstable" to accord the federal government exclusive power over immigration enforcement, while allowing states and localities to "choose different methods of integrating immigrants"7-suggested that the Court's reaffirmation of federal primacy in the sphere of immigration enforcement signaled the demise of "immigration federalism,"8 or at the very least a return to state inaction in both immigration and alienage rulemaking. ${ }^{9}$ I disagree. Arizona v. United States may mark a watershed in U.S. immigration law and policy, but it does not mark the end of state and local engagement in immigration regulation. Instead, it portends a "new" direction for "immigration federalism." The Arizona Court's reinvigoration of the doctrine of broad federal power in the immigration arena does not foreclose all state action pertaining to immigrants and immigration. Rather, the post-Arizona legal landscape provides ample opportunity for different varieties of state and local engagement with noncitizen residents-some of which will be novel and some of which will involve the further development or redirection of preexisting laws and policies. This "new immigration federalism" is and will be grounded in immigrant-inclusionary

${ }^{5}$ In 2012, the number of new state laws pertaining to immigration was reduced to 156 . 2012 Immigration-Related Laws and Resolutions in the States (Jan. 1-Dec. 31, 2012), NAT'L CONF. OF STATE LEGISLATURES, http:/www.ncsl.org/issues-research/immig/2012-immigr ation-related-laws-jan-december-2012.aspx (last visited Oct. 13, 2013).

${ }^{6}$ See Arizona, 132 S. Ct. at 2502.

${ }^{7}$ Cristina M. Rodriguez, The Significance of the Local in Immigration Regulation, 106 MiCH. L. REV. 567, 618 (2008); see also Michael J. Wishnie, Laboratories of Bigotry? Devolution of the Immigration Power, Equal Protection, and Federalism, 76 N.Y.U. L. REV. 493, 509-10 (2001) [hereinafter Wishnie, Laboratories].

${ }^{8}$ See, e.g., Andrew Pincus, Online Symposium: $A$ Win for the Government and for the $S G$, SCOTUSBLOG (June 26, 2012, 4:56 PM), http://www.scotusblog.com/2012/06/onlinesymposium-a-win-for-the-government-and-for-the-sg/ ("[T]his is a big win for the United States."); Margaret Stock, Online Symposium: The Court Throws Arizona a Tough Bone To Chew, SCOTUSBLOG (June 27, 2012, 4:51 PM), http://www.scotusblog.com/2012/06/ online-symposium-the-court-throws-arizona-a-tough-bone-to-chew/ ("The Court's five-tothree decision in Arizona $v$. United States appears to be a resounding victory for the Obama Administration-legally and politically.").

${ }^{9}$ See Pratheepan Gulasekaram \& S. Karthick Ramakrishnan, Immigration Federalism: A Reappraisal, 88 N.Y.U. L. REV (forthcoming 2013); David S. Rubenstein, Immigration Structuralism: A Return to Form, 8 DUKE J. CONST. L. \& PUB. POL'Y 101, 138-40, 160-62 (2013). 
rulemaking, which has the potential to complement (as well as occasionally contradict) federal efforts at comprehensive immigration reform.

Early analyses of post-Arizona state lawmaking support this understanding of the new framework of immigration federalism. After a lull during 2012, which coincided with the Court's consideration of Arizona, state rulemaking pertaining to immigrants rebounded in the first six months of 2013. By the end of June of 2013, forty-three states and the District of Columbia had passed a total of 377 laws and resolutions related to immigration; an $83 \%$ increase from the first half of 2012.10 Notably, just one state, Georgia, passed immigrantexclusionary legislation in early 2013; the other forty-two states enacted immigrant-inclusionary measures. ${ }^{11}$ Legislation intended to expand access to driver's licenses for all immigrants was introduced in at least nineteen states, as well as in the District of Columbia and Puerto Rico. ${ }^{12}$ Bills designed to provide access to in-state tuition rates for students, regardless of their immigration status, so-called "State DREAM Acts," were introduced in at least sixteen states, and proposals for greater access to scholarships and/or financial aid for immigrant students were considered in several states. ${ }^{13}$ At the same time, five state legislatures debated new measures to provide greater workplace protections to immigrant domestic workers. ${ }^{14}$ These recent developments portend the future direction of immigration federalism in the United States.

Part II of this Article explains why "immigration federalism," a term that has hitherto been defined narrowly, with an emphasis on anti-unauthorizedimmigrant laws, should now be defined more broadly, to encompass all multigovernmental rulemaking pertaining to immigrants and immigration-including rulemaking intended to foster immigrant inclusion--undertaken by various government entities acting in cooperation with or in opposition to one another.

Part III of the Article analyzes the Supreme Court's 2012 ruling in Arizona v. United States ${ }^{15}$ and 2011 ruling in Chamber of Commerce $v$. Whiting, ${ }^{16}$ the two cases that provide the doctrinal parameters for the new immigration

${ }^{10}$ See Nat'l CONFERenCe of State Legislatures, Immigrant Policy Project 1 (Sept. 2013), http://www.ncsl.org/issues-research/immig/immgration-report-august-2013. aspx.

11 See Nat'l Immigration Law CTR., INClusive Policies AdVANCE Dramatically IN THE STATES (2013), http://www.nilc.org/pubs.html\#statesessions.

12 At the start of the 2013 legislative session, Washington, New Mexico, and Utah issued driver's licenses irrespective of immigration status. Now Illinois, Maryland, Oregon, Nevada, Colorado, Vermont, Connecticut, and Puerto Rico issue licenses to all residents, and similar bills are pending in Washington, D.C., California, Minnesota, Kentucky, and Iowa. See id. at 2-4.

${ }^{13}$ See id. at 6-7.

${ }^{14}$ See id. at 11.

15 132 S. Ct. 2492 (2012).

16131 S. Ct. 1968, 1981 (2011) (holding that the Immigration Reform and Control Act of 1986 does not preempt an Arizona statute that mandates additional requirements on employers who hire immigrant employees and imposes punitive sanctions on those who hire unauthorized workers). 
federalism. Parts IV and V of the Article then discuss the potential effect of the Court's recent immigration federalism doctrine on current and future regulation of immigrants by the federal, state, and local governments-in other words, these Parts sketch out the landscape of the new, post-Arizona, immigration federalism. ${ }^{17}$

Part IV discusses immigrant-exclusionary state and local rulemaking, including (i) expressly delegated direct enforcement, (ii) independent direct enforcement, and (iii) indirect enforcement measures that are undertaken both with and without delegation from the federal government. Part IV argues that, in light of Arizona v. United States and Chamber of Commerce v. Whiting, states' and localities' opportunities for promulgating their own direct immigration enforcement laws have been strictly curtailed, so that state and local indirect enforcement measures are no longer permissible.

Part V analyzes immigrant-inclusionary state and local rulemaking, including (i) comprehensive sanctuary ordinances, and (ii) education access legislation. Part V argues that now, more than ever, there are clear opportunities for states and localities to engage in various and different immigrantinclusionary measures, even when those measures may lead them to both complement and contradict federal government initiatives.

In sum, the Article proposes that Arizona v. United States does not signal the end of "immigration federalism," but rather its redefinition, redirection, and further development. The Court's decision limits states' and localities' ability to engage in immigrant-exclusionary lawmaking, but it also compels a new focus on states' and localities' continued ability to develop laws designed to foster immigrant inclusion. Such innovative lawmaking can and should be an integral part of the national debate about comprehensive immigration reform. The Article therefore concludes with observations on future challenges and potential opportunities posed by the new immigration federalism, within the broader context of comprehensive immigration reform.

\section{II. (RE)DEFINING “IMMIGRATION FEDERALISM”}

"Immigration federalism" is a freighted term. In this Article, I propose that "immigration federalism" be defined expansively as: "the engagement by national, state, and local governmental actors in immigration regulation." Such a broad definition departs somewhat from prior usage of the term. Although immigration law scholars have previously defined the term "immigration federalism" in a variety of ways, ${ }^{18}$ most have adopted narrow definitions that

${ }^{17}$ In so doing, these Parts of the Article build on the work of Peter Schuck in 2007 and Cristina Rodriguez in 2008. See generally Rodriguez, supra note 7; Peter H. Schuck, Taking Immigration Federalism Seriously, 2007 U. CHI. LEGAL F. 57.

${ }^{18} \mathrm{See}$, e.g., Clare Huntington, The Constitutional Dimension of Immigration Federalism, 61 VAND. L. REV. 787, 788 (2008); Schuck, supra note 17, at 66-67; Peter J. Spiro, Learning To Live with Immigration Federalism, 29 CONN. L. REV. 1627, 1635-36 (1997). Each of these scholars has, however, emphasized the centrality of immigration 
imply "immigration federalism" is synonymous with "immigration enforcement federalism." 19 This is understandable, given the prominence of numerous antiunauthorized-immigrant laws and policies in several states and localities, such as Arizona's controversial Support Our Law Enforcement and Safe Neighborhoods Act ("S.B. 1070") $)^{20}$ or Hazleton, Pennsylvania's Illegal Immigration Relief Act. ${ }^{21}$ But, a narrow definition paints an incomplete picture of state and local engagement in immigration-related rulemaking to date, and fails to account for the potential flourishing of immigrant-inclusionary lawmaking in the post-Arizona era.

enforcement as a defining component of "immigration federalism." Indeed, Professor Rodriguez claimed that it would be "conceptually unstable" for states to promulgate immigrant-inclusionary laws without also engaging in immigrant-exclusionary rulemaking. See Rodriguez, supra note 7, at 618. I contend that in the aftermath of Arizona this is no longer the case.

${ }^{19}$ As a consequence of such narrow definitions, those scholars who are most concerned with discrimination against immigrants were perceived as being opposed to "immigration federalism." See, e.g., Huntington, supra note 18, at 789 n.7 (citing Wishnie, Laboratories, supra note 7 , at $515-18,527-28$ as "describing discriminatory state laws passed pursuant to a federal law permitting states to determine eligibility of non-citizens for public benefits and anticipating more such laws in the next economic downturn"). Such commentators argued persuasively that devolving authority, particularly in the sphere of immigration enforcement, to state and local authorities could have a profoundly detrimental effect on immigrant communities, see Michael J. Wishnie, State and Local Police Enforcement of Immigration Laws, 6 U. PA. J. CoNST. L. 1084, 1088-95 (2004) [hereinafter Wishnie, State] (arguing that state and local police have no "inherent authority" to enforce federal immigration laws and that any enforcement authority they may have has been preempted by federal law), could encourage racial profiling by police, see Huyen Pham, The Constitutional Right Not To Cooperate? Local Sovereignty and the Federal Immigration Power, 74 U. CIN. L. REV. 1373, 1400-01 (2006) ("[I]f local authorities start enforcing immigration laws without proper training, they are prone to engage in racial profiling or other abuses of authority."); Wishnie, State, supra, at 1102-15 (describing concern of racial profiling with increased use of state and local enforcement of federal immigration law), and could also discourage immigrant victims of crime from coming forward, see Orde F. Kittrie, Federalism, Deportation, and Crime Victims Afraid To Call the Police, 91 IowA L. REV. 1449, 1450-55 (2006) (describing disincentives for unauthorized migrants to report crimes to the police). In contrast, commentators who advocate for tighter control of migration and more aggressive enforcement of immigration laws were often perceived as being in favor of "immigration federalism." See Huntington, supra note 18, at 789 n.10 (describing Kris W. Kobach, The Quintessential Force Multiplier: The Inherent Authority of Local Police To Make Immigration Arrests, 69 ALB. L. REV. 179, 183-99 (2005) as "listing situations in which immigration-based arrests by state and local officials have been crucial"); Jeff Sessions \& Cynthia Hayden, The Growing Role for State \& Local Law Enforcement in the Realm of Immigration Law, 16 STAN. L. \& POL'Y REV. 323, 327-29 (2005) (describing the need for state and local enforcement of federal immigration law).

${ }^{20}$ S.B. 1070, 49th Leg., 2d Reg. Sess., Ch. 113 (Ariz. 2010) (as amended by H.B. 2162); see also H.B. 2162, 49th Leg., 2d Reg. Sess., Ch. 211 (Ariz. 2010) (amending S.B. 1070).

${ }^{21}$ Hazleton, Pa., Ordinance 2006-18 $\S 5,7 . B$ (2006) (prohibiting landlords from harboring unlawful immigrants). 
Indeed, for many years, immigrant-exclusionary measures have been far from the whole story of state and local engagement with local immigrant communities, and using the term "immigration federalism" in a narrowly proscribed manner ignores the multiplicity of existing forms of involvement by state and local actors in immigration-related rulemaking. ${ }^{22}$ Just as some states and localities have long sought to exclude immigrants, others have long sought to welcome and include them, irrespective of the immigrants' legal status. Indeed, in the summer of 2012, in the days before the Arizona opinion issued, the California Senate passed a bill prohibiting state police and sheriff's officials from holding certain immigrant detainees pending deportation, ${ }^{23}$ and the Mayor of Chicago proposed an ordinance barring city police officers from surrendering undocumented migrants without criminal records to federal officers. ${ }^{24}$ The proliferation of widely divergent state and local legislation either constraining or promoting immigrants' employment, education, housing, access to government benefits, participation in civic life, and sentencing for criminal and immigration offenses ${ }^{25}$ cautions against viewing "immigration federalism" as pertaining only to immigrant-exclusionary measures. Thus, any definition of "immigration. federalism" that focuses primarily on exclusion fails to capture fully the range of federal, state, and local lawmaking pertaining to immigrants and immigration. 26

A broad definition of "immigration federalism" is therefore needed to encompass involvement by multiple tiers of government-at the federal, state, and local levels-in the promulgation of laws and regulations implicating immigration and alienage that may pertain to either immigrant exclusion or

\section{${ }^{22}$ See infra Part V.}

${ }^{23}$ See Paloma Esquivel, California Senate OKs Bill that Would Blunt Deportation Efforts, L.A. TIMES, July 6, 2012, at AAl.

${ }^{24}$ Julia Preston \& Steve Yaccino, Obama Policy on Immigrants Is Challenged by Chicago, N.Y. Times, July 11, 2012, at A14.

${ }^{25}$ At one end of the spectrum, cities such as San Francisco have passed "sanctuary" ordinances refusing to participate in federal immigration enforcement and granting a bundle of benefits to undocumented residents. See S.F., CAL., ADMIN. CODE $\$ 12$ H.2 (2005). At the other end of the spectrum towns such as Hazleton, Pennsylvania have passed exclusionary ordinances stating that businesses that employ "illegal aliens" will be denied licenses and landlords that rent homes to such individuals will be fined $\$ 250$, as well as declaring English the city's official language. Hazleton, Pa., Ordinance 2006-18; Hazleton, Pa., Ordinance 2006-19; see Peter Schuck, Some Federal-State Developments in Immigration Law, 58 N.Y.U. ANN. SURV. AM. L. 387, 389-90 (2002).

${ }^{26}$ See, e.g., Marc Lacey, One Family's Debate Shows Arizona Law Divides Latinos, Too, N.Y. TIMES, Oct. 31, 2010, at A20 (describing deep divisions among Arizona's Latino community over S.B. 1070, some of whom support the bill, others of whom oppose it); Ian Lovett, Part of California Takes on Illegal Hiring, N.Y. TimES, Jan. 5, 2011, at A15 (describing conflict between Southern California's "Inland Empire" cities and other areas of the state over restrictions on the employment of undocumented workers); Julia Preston, Lack of Consensus in Legislature Slows Tough Measures on Immigration, N.Y. TIMES, Mar. 14, 2011, at A13 (describing, inter alia, vocal opposition to a variety of state immigration initiatives in Colorado, Kansas, Nebraska, New Mexico, Oklahoma, and Washington). 
immigrant inclusion. (Re)defining "immigration federalism" as "the engagement by national, state, and local governmental actors in immigration regulation," recognizes states' and localities' potential to engage both in antiunauthorized-immigrant rulemaking and in the promulgation of laws designed to foster immigrant inclusion. As this Article will demonstrate, such a broad definition is necessary to accurately capture the new direction of immigration federalism in the aftermath of Arizona and Whiting, wherein immigrantexclusionary rulemaking is broadly constrained, whilst immigrant-inclusionary lawmaking is not. This broad definition of "immigration federalism" also implicitly acknowledges that allowing the immigration debate to play out at multiple levels may provide an opportunity for a variety of different legislative and regulatory outcomes. ${ }^{27}$ Immigration rulemaking, the enforcement of those rules, and dissent from those rules now implicate an increasingly complicated patchwork of federal-state, state-local, and in some instances even federallocal or federal-state-local relationships. As I discuss infra, in recent years, despite well-established doctrine mandating federal primacy, states have acted either under the supervision of the federal government, concurrently with the federal government, in competition with the federal government, or in dissent from the federal government to both exclude immigrants and to include them. ${ }^{28}$ Moreover, the engagement by state and local governmental actors in immigration regulation does not necessarily involve state and local authorities acting in uniform ways to cooperate and coordinate their actions with those of the federal government. ${ }^{29}$ The "new immigration federalism," in the postArizona legal landscape, may thus involve differentiated dissenting or uncooperative rulemaking by states and localities, ${ }^{30}$ whether with respect to immigrant-exclusionary measures such as laws directing local police officers to

${ }^{27}$ See Robert M. Cover, The Uses of Jurisdictional Redundancy: Interest, Ideology, and Innovation, 22 WM. \& MARY L. REV. 639, 641 (1981).

${ }^{28}$ See discussion infra. Immigration regulation is, of course, far from the only sphere in which this trend is apparent. Federalism scholars such as Robert Schapiro have analyzed the engagement of different tiers of government, including federal and state executive, legislatures, courts, and agencies, in many areas of the law that involve the "dynamic interplay of federal and state prerogatives." Robert A. Schapiro, Monophonic Preemption, 102 Nw. U. L. REV. 811, 812 (2008); see also Robert A. Schapiro, Justice Stevens's Theory of Interactive Federalism, 74 FORDHAM L. REV. 2133, 2142 (2006); Robert A. Schapiro, Toward a Theory of Interactive Federalism, 91 IOWA L. REV. 243, 249 (2005). Larry Kramer has also explored interest-based bargaining in specific circumstances-the administration of intergovernmental programs. See Larry Kramer, Understanding Federalism, 47 VAND. L. REV. 1485, 1544 (1994); see also Larry D. Kramer, Putting the Politics Back into the Political Safeguards of Federalism, 100 COLUM. L. REV. 215, 283 (2000) (describing "the political ties that bind federal and state officials and the bureaucratic connections forged through cooperative federalism as different features of the 'political safeguards of federalism"').

${ }^{29} 287(\mathrm{~g})$ agreements between Immigration and Customs Enforcement and state and local police, which are discussed in detail infra Part IV, are the exception to this rule.

${ }^{30}$ See Jessica Bulman-Pozen \& Heather K. Gerken, Uncooperative Federalism, 118 YALE L.J. 1256, 1271-72 (2009). 
question individuals about their immigration status or immigrant-inclusionary measures such as the sanctuary city movement or state DREAM Act legislation. ${ }^{31}$ In sum, a broad and inclusive definition of immigration federalism is now warranted to characterize the current nature and future direction of state, local, and federal engagement with immigration regulation. I turn, therefore, in the next Part of this Article, to the parameters of this new immigration federalism, as articulated in the United States Supreme Court's recent immigration preemption cases.

\section{THE NEW IMMIGRATION PREEMPTION DOCTRINE}

The United States Constitution does not expressly define the scope of federal power to regulate immigration. ${ }^{32}$ In the late nineteenth century, a series of United States Supreme Court cases delineated federal and state responsibility for regulating the lives of immigrants. ${ }^{33}$ The Court's division of responsibility, which endures to this day, is predicated on a distinction between "immigration law" and "alienage laws." "Immigration law," i.e., legislation governing the selection, admission, and exclusion of noncitizens enshrined in the federal Immigration and Nationality Act ("INA"), ${ }^{34}$ is the exclusive purview of the federal government, which enjoys vast or "plenary" power in this area. ${ }^{35}$ In contrast, "alienage laws," which are laws that determine the rights, privileges, and obligations of noncitizens present in the United States, can, according to the

${ }^{31}$ State enforcement of immigration laws is discussed in Part IV infra, state promulgation of sanctuary laws is discussed in Part V.A infra, and state DREAM Acts are discussed in Part V.B infra.

${ }^{32}$ See Sarah H. Cleveland, Powers Inherent in Sovereignty: Indians, Aliens, Territories, and the Nineteenth Century Origins of Plenary Power over Foreign Affairs, 81 TEX. L. REV. 3, 81-83 (2002) (describing the Naturalization Clause, the Migration Clause, the Taxation Clause, and the treaty, foreign commerce, and war powers as plausible enumerated sources of the federal government's immigration powers).

${ }^{33}$ See generally Fong Yue Ting v. United States, 149 U.S. 698 (1893); Chae Chan Ping v. United States, 130 U.S. 581 (1889); Chy Lung v. Freeman, 92 U.S. 275 (1875).

${ }^{34}$ Immigration and Nationality Act of 1952, Pub. L. No. 82-414, 66 Stat. 163 (codified as amended in scattered sections of 8 U.S.C. (2012)); see also Takahashi v. Fish \& Game Comm'n, 334 U.S. 410, 419 (1948) (defining immigration law to concern "what aliens shall be admitted to the United States, the period they may remain, regulation of their conduct before naturalization, and the terms and conditions of their naturalization"). Typical "immigration" laws include, for example, Section 1182 of the Immigration and Nationality Act, which sets forth the general classes of aliens "ineligible to receive visas and ineligible to be admitted," 8 U.S.C. $\S 1182$ (2012), and the Refugee Act of 1980, Pub. L. No. 96-212, 94 Stat. $102(2012)$.

${ }^{35}$ On the unique usage of the term "plenary power" in the immigration context, see, e.g., STEPHEN H. LEGOMSKY, IMMIGRATION AND THE JUdiCIARY: LAW AND POLITICS IN BRITAN AND AMERICA 177-222 (1987); Peter H. Schuck, The Transformation of Immigration Law, 84 COLUM. L. REV. 1, 15, 57 (1984). 
same longstanding doctrine, be enacted by either the federal government or the states. 36

In two recent cases involving immigration-related rulemaking by the State of Arizona, Arizona v. United States ${ }^{37}$ and Chamber of Commerce v. Whiting, ${ }^{38}$ the United States Supreme Court has clarified what rulemaking by state and local lawmakers constitutes impermissible "immigration" legislation and what constitutes permissible "alienage" legislation. In so doing, the Court provides the basic doctrinal framework for the future development of immigration federalism.

\section{A. Arizona v. United States and Immigration Preemption}

On June 25, 2012, the Supreme Court published its opinion in Arizona v. United States, ${ }^{39}$ which held that three of four contested provisions in Arizona's Support Our Law Enforcement and Safe Neighborhoods Act ("S.B. 1070") 40 were preempted by federal law. Justice Kennedy's majority opinion rejects, on field and obstacle preemption grounds, all but one of the provisions at issue and reaffirms federal primacy in "immigration" rulemaking while concurrently permitting some measure of state "alienage" legislation. ${ }^{41}$

The provisions of S.B. 1070 at issue in the case were Sections 2(B), 3, 5(C), and 6 of the Act. Section 2(B) of S.B. 1070 requires state officers to make a "reasonable attempt ... to determine the immigration status" of any person they stop, detain, or arrest on some other legitimate basis if "reasonable suspicion exists that the person is an alien and is unlawfully present in the United States." 42 The Section further provides that "[a]ny person who is arrested shall have the person's immigration status determined before the person is

${ }^{36}$ For example, in a series of cases, the Court recognized the power of a state to restrict the devolution of real property to noncitizens based on a state's broad authority to regulate real property within its borders. See Frick v. Webb, 263 U.S. 326, 333-34 (1923) (noting that the exercise of such power does not violate the Due Process or Equal Protection Clauses of the Fourteenth Amendment); Webb v. O'Brien, 263 U.S. 313, 321-22 (1923) (same); Porterfield v. Webb, 263 U.S. 225, 233 (1923) (same); Terrace v. Thompson, 263 U.S. 197, 216-18 (1923) (same). Another typical alienage law might, for example, specify that only U.S. citizens may be employed in state-funded jobs, such as public school teaching. See, e.g., Harold Hongju Koh, Equality with a Human Face: Justice Blackmun and the Equal Protection of Aliens, 8 HAMLINE L. REV. 51, 61-62 (1985). For an alternative account of the distinctions between immigration laws and alienage laws, see Gulasekaram, supra note 9.

${ }^{37}$ See Arizona v. United States, 132 S. Ct. 2492, 2502 (2012).

38 See Chamber of Commerce v. Whiting, 131 S. Ct. 1968, 1987 (2011).

${ }^{39}$ Arizona, 132 S. Ct. at 2503, 2505, 2507.

${ }^{40}$ S.B. 1070, 49th Leg., 2d Reg. Sess., Ch. 113 (Ariz. 2010) (as amended by H.B. 2162); see also H.B. 2162, 49th Leg., 2d Reg. Sess., Ch. 211 (Ariz. 2010) (amending S.B. 1070).

${ }^{41}$ For an alternative interpretation of Justice Kennedy's opinion, see generally Rubenstein, supra note 9 (arguing that Arizona is an "alienage" case, rather than an "immigration" case).

42 ARIZ. REV. STAT. ANN. § 11-1051(B) (Supp. 2012). 
released."43 Section 3 of the Act creates a new state misdemeanor forbidding the "willful failure to complete or carry an alien registration document ... in violation of 8 United States Code section 1304(e) or 1306(a)."44 Section 5(C) creates a new state misdemeanor for "an unauthorized alien to knowingly apply for work, solicit work in a public place or perform work as an employee or independent contractor." 45 Section 6 provides that a state police or sheriff's officer, "without a warrant, may arrest a person if the officer has probable cause to believe ... [the person] has committed any public offense that makes [him] removable from the United States."46

The United States District Court for the District of Arizona preliminarily enjoined the entry into force of S.B. 1070 in 2010 on federal preemption grounds ${ }^{47}$ and the United States Court of Appeals for the Ninth Circuit affirmed that decision in 2011.48 The Ninth Circuit held that S.B. 1070 likely "subverts Congress's intent that systematic state immigration enforcement will occur under the direction and close supervision of the Attorney General" and "is inconsistent with the discretion Congress vested in the Attorney General to supervise and direct State officers in their immigration work according to federally-determined priorities." 49 The Ninth Circuit concluded that the Arizona statute was likely preempted because it prevents the uniform enforcement of federal immigration law envisaged by Congress, which "intended, and encouraged inter-governmental cooperation between state and federal agencies ... on the federal government's terms." 50

A 5-3 majority of the Supreme Court agreed, with respect to Sections 3, 5(C), and 6 of the statute. ${ }^{51}$ The Court's opinion in Arizona v. United States emphasizes the federal government's "broad, undoubted ... fundamental and complex" power over immigration regulation, based on the Naturalization Clause and its inherent power as the national sovereign to control and conduct foreign relations. ${ }^{52}$ The opinion reaffirms the traditional doctrinal understanding of the national government as a "single sovereign" in charge of "a comprehensive and unified system to keep track of aliens within the Nation's

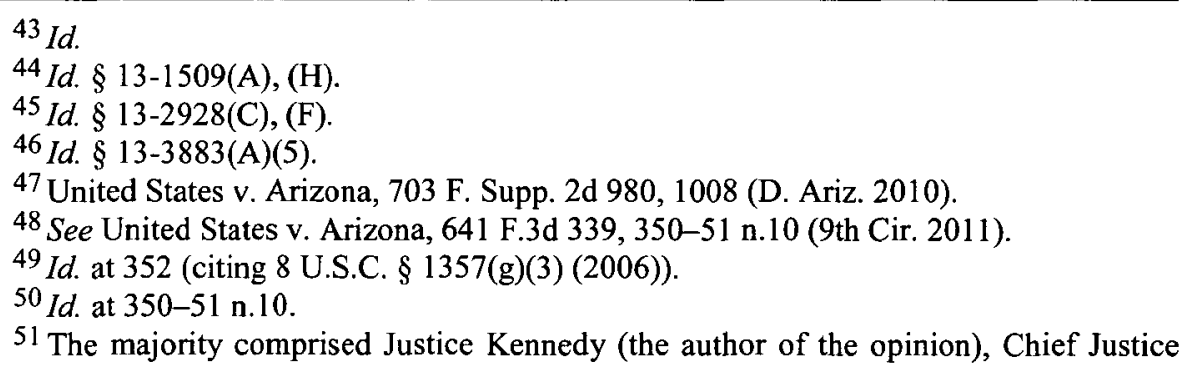
Roberts, Justice Breyer, Justice Ginsburg, and Justice Sotomayor. Justice Alito concurred in part with the majority opinion (insofar as it pertained to Section 3 and 2(B) of the Arizona statute) and filed a separate dissent. Justices Scalia and Thomas each also filed separate dissents and concurrences. Justice Kagan took no part in the deliberations. Arizona v. United States, 132 S. Ct. 2492, 2497, 2510, 2524 (2012).

${ }^{52}$ See id. at 2498 (citing Toll v. Moreno, 458 U.S. 1, 10 (1982) and U.S. CONST. art. I, $\S 8, \mathrm{cl} .4)$. 
borders." 53 It also emphasizes the "fundamental" importance, on foreign policy grounds, of a unified national immigration policy under federal control that enables foreign countries to communicate with one national government about immigration issues. ${ }^{54}$ The opinion notes that this uniformity is particularly important with respect to immigration enforcement regulations and policies because "[ $t]$ he dynamic nature of relations with other countries requires the Executive Branch to ensure that enforcement policies are consistent with this Nation's foreign policy with respect to these and other realities." 55 Hence, the opinion suggests, the federal government enjoys "broad discretion" in determining whether and how to enforce immigration laws pertaining to immigrant selection, admission, and removal.

This conception of federal immigration regulation as a "harmonious whole" is evident throughout the Court's opinion in Arizona $v$. United States. ${ }^{56} \mathrm{With}$ respect to Section 3 of S.B. 1070, which creates a new state misdemeanor for failure to carry a federal alien registration document, the opinion holds that Congress has provided the full and only set of standards used to govern when and how immigrants must register with the federal government. ${ }^{57}$ Therefore, any state regulations-whether more extensive than the federal scheme (like Section 3 of the Arizona law) or identical to the federal requirements-are impermissible under the Court's long established field preemption doctrine. ${ }^{58}$ As a consequence, the opinion holds, states may not introduce their own alien registration schemes, even if they claim that they have the same aim as federal law and are designed. merely to complement, or mirror the federal scheme. 59 Nonetheless, the Court appears to be particularly concerned by the extent to which S.B. 1070 seeks to supplement the federal regulations by adopting a more punitive approach that might be at odds with federal policies and priorities. "Were [Section] 3 to come into force," the opinion notes, "the State would have the power to bring criminal charges against individuals for violating a federal

${ }^{53} \mathrm{Id}$. at 2502 .

${ }^{54}$ See id. at 2498 (citing Brief for Madeleine K. Albright, William S. Cohen, Rudolph F. DeLeon, Conrad K. Harper, Donald L. Kerrick, Lawrence J. Korb, John D. Negroponte, Davis R. Robinson, and William H. Taft IV as Amici Curiae Supporting Respondent, Arizona, 132 S. Ct. 2492 (No. 11-182)).

${ }^{55}$ Id . at 2499. Justice Scalia alone made an argument that states have the same power the national government does to use their borders as barriers to entry of unwanted individuals. Id. at 2512 (Scalia, J., concurring in part and dissenting in part).

${ }^{56} I d$. at 2502 (majority opinion).

${ }^{57}$ Arizona, 132 S. Ct. at 2503.

${ }^{58} \mathrm{Id}$. at 2502. The Court, citing Hines v. Davidowitz, 312 U.S. 52, 72 (1941), suggests that where, as with alien registration, Congress has occupied an entire field with a complex and comprehensive regulatory scheme, even "complementary" state regulation is impermissible.

${ }^{59}$ Kris Kobach, the Kansas Secretary of State, who advised Arizona Governor Jan Brewer on S.B. 1070, has been an outspoken proponent of a "mirroring" theory of state immigration enforcement laws. See Kris Kobach, The Fiscal and Legal Foundation of State Laws on Illegal Immigration, 51 WASHBURN L.J. 201, 208 (2012). 
law even in circumstances where federal officials in charge of the comprehensive scheme determine that prosecution would frustrate federal policies."60 Furthermore, the Court observes, "[e]ven where federal authorities believe prosecution is appropriate, there is an inconsistency between [Section] 3 and federal law with respect to penalties," 61 with the Arizona scheme precluding the more lenient sentence of probation or the possibility of an eventual pardon (which would be available under federal law).

Similar concerns pervade the Court's rejection of Section 5(C) of S.B. 1070, the provision creating a new state misdemeanor for undocumented immigrants who "apply for work, solicit work in a public place or perform work as an employee or independent contractor."62 Under Section 5(C) such conduct is punishable by a fine of $\$ 2,500$ and incarceration for a period of up to six months. ${ }^{63}$ This provision of the Arizona Act exceeds the scope of the federal law governing immigrant employment, the Immigration Reform and Control Act of 1986 ("IRCA"), ${ }^{64}$ which imposes sanctions on employers who knowingly hire undocumented workers, but which does not penalize the immigrant workers themselves. ${ }^{65}$ The opinion holds that this distinction in the federal Act was crucially important, stating that "[ $t]$ he legislative background of IRCA underscores the fact that Congress made a deliberate choice not to impose criminal penalties on aliens who seek, or engage in, unauthorized employment."66 Thus, the opinion concludes, Section 5(C) of S.B. 1070 "would interfere with the careful balance struck by Congress with respect to unauthorized employment of aliens," 67 and would therefore be "an obstacle to the regulatory system Congress chose." 68 As such, the Court held, Section 5(C) was preempted by federal law.

The Court's concern that the Arizona statute conflicted with the federal government's established priorities and policies was also evident in its ruling that Section 6 of S.B. 1070 was preempted. According to the Court, Section 6, which permits a state police officer to arrest, without a warrant, any individual whom the officer has probable cause to believe is removable, ${ }^{69}$ "violates the principle that the removal process is entrusted to the discretion of the Federal Government."70 The opinion notes that, as a general rule, it is "not a crime for a removable alien to remain present in the United States,"71 but rather a civil

${ }^{60}$ Arizona, 132 S. Ct. at 2503; see ARIZ. REV. STAT. ANN. $\$ 13-2928(C)$ (Supp. 2011).

${ }^{61}$ Arizona, 132 S. Ct. at 2503.

${ }^{62} \mathrm{Id}$.

${ }^{63} \mathrm{Id}$.

64 8 U.S.C. $\$ 1324$ (a)-(b) (2012).

65 Arizona, 132 S. Ct. at 2504.

${ }^{66} \mathrm{Id}$.

${ }^{67} I d$. at 2505 .

${ }^{68} \mathrm{Id}$.

${ }^{69}$ ARIZ. REV. STAT. ANN $\S 13-3883($ A)(5) (Supp. 2012).

${ }^{70}$ Arizona, 132 S. Ct. at 2506.

${ }^{71} \mathrm{Id}$. at 2505 . 
violation, and that the federal statutory structure determines when it is appropriate to arrest an alien during the removal process. The opinion states that Section 6 of the Arizona Act nonetheless "attempts to provide state officers with even greater authority to arrest aliens on the basis of possible removability than Congress has given to federal immigration officers." 72 The latitude given to state police and sheriff's officers under Section 6 to conduct a warrantless arrest on the basis of belief that an alien had committed any "public offense," without regard to the alien's flight risk or to the federal interest in the alien's detention, is therefore an impermissible usurpation of the federal prerogative to determine enforcement priorities. "This would allow the State to achieve its own immigration policy," the opinion notes disapprovingly ${ }^{73}$ which "is not the system Congress created." 74 The opinion concedes that there were circumstances in which federal-state cooperation in immigration enforcement was both permissible and desirable, ${ }^{75}$ but that while there may be "some ambiguity" as to what might constitute cooperation in enforcement operations under the federal law, "no coherent understanding of the term would incorporate the unilateral decision of state officers to arrest an alien for being removable absent any request, approval, or other instruction from the Federal Government." 76 The Court was particularly concerned that unilateral action by state police or sheriff's officers could lead to the unnecessary arrest and detention of certain classes of undocumented immigrants, such as veterans, college students, or individuals assisting with criminal investigations, whom federal officials would not wish to arrest or remove. ${ }^{77}$

Notwithstanding its apparent concern that state officers acting under cover of Section 6 of S.B. 1070 might act precipitously to arrest certain types of undocumented immigrants, the Court declined to hold that the remaining contested provision of S.B. 1070, Section 2(B), was preempted on its face by federal law. ${ }^{78}$ Colloquially known as the "show me your papers" provision, Section 2(B) requires state police and sheriff's officers, whenever they make any arrest for any suspected violation of any law and have "reasonable suspicion" to believe that the individual is an undocumented immigrant, to detain that individual until they can check his immigration status. ${ }^{79}$ The Court,

${ }^{72} \mathrm{Id}$. at 2506.

${ }^{73} \mathrm{Id}$. In contrast, Justice Scalia in dissent declared that independent state immigration laws were both permissible and desirable. Id. at 2514-16 (Scalia, J., concurring in part and dissenting in part) (No federal law says that the states cannot have their own immigration law. "Arizona is entitled to have 'its own immigration policy." Id. at 2516.).

${ }^{74} \mathrm{Id}$. at 2506 . The Court mentions both $287(\mathrm{~g})$ agreements and the "significant complexities involved in enforcing federal immigration law, including the determination whether a person is removable," and cites to its opinion in Padilla v. Kentucky, 559 U.S. 356, 376-81 (2010).

\footnotetext{
${ }^{75}$ See discussion infra Part IV.A.

76 Arizona, 132 S. Ct. at 2507.

${ }^{77} \mathrm{Id}$. at 2506.

${ }^{78} \mathrm{Id}$. at 2507.

${ }^{79} \mathrm{Id}$.
} 
viewing this provision as an "alienage" rule, consistent with the state's valid exercise of its police powers, held that the requirement of S.B. 1070's Section 2(B), as it appears in the text of the law, is neither in conflict with nor an obstacle to federal law,, 80 although the Court added that such a holding does not bar any potential "as applied" challenges that might be made to the law after it goes into effect. ${ }^{81}$ The Court observed that under federal law "no state or local government entity may be prohibited, or in any way restricted, from sending to or receiving from [ICE] information regarding the immigration status, lawful or unlawful, of an alien in the United States." 82 The federal Immigration and Nationality Act thus "leaves room for a policy requiring state officials to contact [Immigration and Customs Enforcement] as a routine matter." 83

The Court speculated as to how Section 2(B) might be implemented and suggested that even in situations in which Arizona police and sheriff's officers contact ICE about immigrants whom the Attorney General does not wish to remove, "Congress has done nothing to suggest it is inappropriate to communicate with ICE." 84 In so doing, the Court drew an explicit parallel with its 2011 ruling in Chamber of Commerce v. Whiting 85 in which it held, inter alia, that the state of Arizona could permissibly require employers to communicate with the federal government using the latter's "E-Verify" database to determine whether potential workers were eligible for employment. ${ }^{86}$ The Court noted, however, that the continued vitality of Section 2(B) of S.B. 1070 would be dependent upon its practical operation and thus on whether the Section 2(B) mandate is interpreted narrowly or expansively. Officers acting under their Section 2(B) authority could potentially detain immigrants without sufficient justification or for too lengthy a period of time. The federal government did not, however, challenge the law on Equal Protection grounds, and thus the Court did not consider the potential for racial

${ }^{80} \mathrm{Id}$. at 2510.

${ }^{81} \mathrm{Id}$. In so ruling, the Court noted that because the provision has not yet entered into practical operation, state courts have yet to interpret its scope. Pointing to language in the Act prohibiting police officers from considering race or national origin in enforcing the law, the Court suggested that racial profiling might not occur.

82 Arizona, 132 S. Ct. at 2508 (citing 8 U.S.C. $\$ 1644$ (2000)).

$83 \mathrm{ld}$.

${ }^{84} \mathrm{Id}$.

85 See infra Part III.B.

${ }^{86}$ Chamber of Commerce v. Whiting, 131 S. Ct. 1968, 1975 (2011). E-Verify is a Department of Homeland Security database administered by United States Citizenship and Immigration Services ("USCIS"). USCIS describes the program as "an Internet-based system that compares information from an employee's Form I-9, Employment Eligibility Verification, to data from U.S. Department of Homeland Security and Social Security Administration records to confirm employment eligibility." What Is E-Verify?, U.S. CITIZENSHIP \& IMMIGR. SERVICES (Nov. 1, 2012), http://www.uscis.gov/portal/site/us cis/menuitem.eb1d4c2a3e5b9ac89243c6a7543f6d1a/?vgnextoid=e94888e60a4051 10VgnVC M1000004718190aRCRD\&vgnextchannel=e94888e60a4051 10VgnVCM1000004718190aR CRD. 
profiling of immigrants by Arizona officers, although it stated explicitly that future suits addressing this issue were not precluded by its ruling. ${ }^{87}$ Indeed, the Court made clear that this decision was not intended to resolve any other constitutional challenges, including "as applied" challenges to Section 2(B) that might be brought after the law goes into effect. ${ }^{88}$

Some commentators have interpreted the Arizona v. United States majority opinion as a victory for the federal government and for immigrants' rights advocates. ${ }^{89}$ Others view the opinion as a triumph for Arizona and the other states seeking to introduce tighter regulation of the immigrants living within their borders. ${ }^{90}$ My own view is that this is not a clear-cut victory for either side. The opinion leaves open the possibility for expressly delegated action by state law enforcement personnel and provides for state officers to make independent inquiries into individuals' immigration statuses and to detain such individuals under the auspices of Section 2(B). Nevertheless, the opinion does arguably favor the federal government's arguments about its plenary occupation of the immigration field, and has firmly limited any independent state rulemaking pertaining to immigration enforcement. Some scholars have suggested that the opinion is too vague, characterizing it as the latest of a series of abstract and unclear immigration rulings by the Court that assert the federal government's plenary power over immigration without clearly defining the connection between absolute federal sovereignty and the Court's preemption analysis. ${ }^{91}$ I believe, however, that the central tenets of the opinion are sound and clear; states may not engage in anti-unauthorized-immigrant rulemaking when such action intrudes upon the federal government's plenary power to determine "immigration" law. ${ }^{92}$ But, as I discuss infra, this limitation leaves open the opportunities for state and local rulemaking pertaining to immigrantinclusionary "alienage" laws, because the opinion is silent as to such regulation.

${ }^{87}$ Arizona, 132 S. Ct. at 2510.

$88 \mathrm{Id}$.

${ }^{89}$ See, e.g., David A. Martin, Reading Arizona, 98 VA. L. REV. IN BRIEF 41 (2012), http://www.virginialawreview.org/inbrief.php?s=inbrief\&p=2012/07/15/reading_arizona (describing various reactions to the case); supra note 8 and accompanying text.

${ }^{90}$ See Richard Samp, Online Symposium: A Defeat for the Obama Administration, SCOTUSBloG (June 25, 2012, 7:56 PM), http://www.scotusblog.com/2012/06/onlinesymposium-a-defeat-for-the-obama-administration/ ("The decision to uphold Sec. 2(B) is a strong affirmation of the right of state and local governments to adopt measures to assist in the enforcement of federal immigration law."); Jay Sekulow, Online Symposium: SCOTUS on AZ Immigration: State Sovereignty Is the Issue, SCOTUSBLOG (June 25, 2012, 4:42 PM), http://www.scotusblog.com/?p=147521 ("The Court's decision to uphold the immigration status check provision is a big win for state sovereignty.").

91 See, e.g., Kerry Abrams, Plenary Power Preemption, 99 VA. L. REV. 601, 602 (2013); Adam B. Cox \& Christina M. Rodriguez, The President and Immigration Law, 119 YALE L.J. 458, 461 (2009).

${ }^{92}$ For a similar interpretation of the holding, see Kit Johnson \& Peter Spiro, Immigration Preemption After United States v. Arizona, 161 U. PA. L. REV. ONLINE 100, 105 (2012), http://www.pennlawreview.com/online/161-U-Pa-L-Rev-Online-100.pdf. 
The significance of the Supreme Court's ruling in Arizona v. United States for the future direction of immigration federalism cannot be overstated. For the first time since the introduction of the Arizona statute, and similar ("copycat") laws in Utah, ${ }^{93}$ Indiana, ${ }^{94}$ Georgia, ${ }^{95}$ Alabama, ${ }^{96}$ and South Carolina, ${ }^{97}$ the Court has spoken definitively as to the extent to which states and localities may promulgate laws and initiatives involving immigration enforcement measures. As I discuss in Part IV infra, a plain reading of the Court's doctrinal analysis in Arizona $v$. United States is that the states' ability to legislate in this arena have been severely curtailed, if not entirely prohibited. Arizona $v$. United States thus provides a clear rule as to the outer limits of "immigration" rulemaking. Chamber of Commerce $v$. Whiting similarly delineates the boundaries of state "alienage" legislation, although the boundaries set by the Court in Whiting were subsequently clarified by the Court's Arizona ruling.

\section{B. Chamber of Commerce v. Whiting and Alienage Laws}

Chamber of Commerce $v$. Whiting was brought by a coalition of businesses and immigrants' advocates, with the support of the Obama Administration, in response to the passage in 2007 of the Legal Arizona Workers Act ("LAWA"). ${ }^{98}$ LAWA imposes heavy penalties, including the loss of an operating license, on businesses that intentionally or knowingly hire undocumented workers and requires that Arizona businesses use the federal EVerify ${ }^{99}$ database to check the immigration status of potential employees. ${ }^{100}$ The Supreme Court ruled that LAWA was not preempted because it was a permissible exercise of state powers to regulate its residents-in other words, because it was a permissible "alienage" law. The Court's holding had two bases. First, the Court held that the law is grounded in the state's licensing provisions, which "fall squarely within the federal statute's savings clause,"101 and second, the Court held that the law does not otherwise conflict with federal

${ }^{93}$ H.B. 497, 59th Leg., Gen. Sess. (Utah 2011), available at http://le.utah.gov/ 2011/ bills/hbillent/hb0497.htm.

94 S.B. 590, 117th Gen. Assemb., 1st Reg. Sess., 2011 Ind. Acts 1926, 1954-57 (codified as IND. CoDE $\S \S 12-7-2-185.5,12-32$ and as amended at $\S 22-4-14-9$ (2013)).

${ }^{95}$ H.B. 87, 151 st Gen. Assemb., 1st Reg. Sess. (Ga. 2011), available at http://www1. legis.ga.gov/legis/2011_12/pdf/hb87.pdf.

${ }_{96}$ H.B. 56, 2011 Leg., Reg. Sess. (Ala. 2011), available at http://alisondb.legislature. state.al.us/acas/.

${ }^{97}$ H.B. 4919, 118th Gen. Assemb., 118th Leg., Reg. Sess. (S.C. 2010), available at http://legiscan.com/gaits/view/119288.

${ }^{98}$ H.B. 2779, 48th Leg., 1st Reg. Sess., 2007 Ariz. Sess. Laws 1312 (codified in scattered sections, including ARIZ. REV. STAT. ANN. § 23-212 (LexisNexis 2007)).

${ }^{99}$ See supra note 86 (describing E-Verify).

${ }^{100}$ Chamber of Commerce v. Whiting, 131 S. Ct. 1968, 1990 (2011).

${ }^{101}$ Immigration and Nationality Act, 8 U.S.C. $\S 1324 \mathrm{a}(\mathrm{h})(2)$ (2012). Federal law preempts "any State or local law imposing civil or criminal sanctions (other than through licensing and similar laws) upon those who employ ... unauthorized aliens." Id. 
law. ${ }^{102}$ The Court emphasized that LAWA "closely track[ed]" the federal law, including its incorporation of a good-faith compliance defense and that it did not upset the balance that IRCA created between different competing governmental interests. ${ }^{103}$ The Court suggested that LAWA maintained that balance because its sanctions were for egregious violations only and, as such, did not exceed in severity those of the federal scheme and because LAWA's requirement that employers use the federal E-Verify database would minimize potential conflicts with federal law. 104

It is worth noting that LAWA, an ostensible "alienage" law, has very real "immigration" law consequences. It reduces the incentive for employers to hire undocumented workers and therefore indirectly discourages undocumented individuals from remaining in Arizona. Laws imposing similar employersanctions, modeled on Arizona's LAWA, were also passed in a number of other states. ${ }^{105}$ In the immediate aftermath of Chamber of Commerce v. Whiting, some commentators suggested that not only would such state laws designed to restrict the employment of immigrants be permitted to go into effect, but also that local ordinances designed to restrict immigrants' access to housing or benefits, such as the so-called "Illegal Immigrant Relief Acts" ("IIRAs") passed in Hazleton, Pennsylvania and Farmers Branch, Texas, might even be permissible. ${ }^{106}$ Such an argument was predicated on the notion that, under Whiting, in the absence of a clear statement of federal law on a given issue, states and cities were permitted to legislate in the interstices.

The Court's ruling in Arizona v. United States, however, substantially reframes the precedent of Whiting, both in the narrow context of immigrant employment and in the wider context of other indirect enforcement laws. ${ }^{107}$ The Court's rejection of Section 5 of S.B. 1070, which penalizes undocumented immigrant workers, not employers, signals clearly that Whiting's rule will not be expanded in any way. Moreover, the Arizona Court actually emphasizes key points made by the Whiting dissenters, such as "the careful balance struck by Congress with respect to unauthorized employment of aliens" in IRCA and the "comprehensive" framework provided by the federal law. ${ }^{108}$ The Court's emphasis on the comprehensive nature of the federal scheme, both in terms of

102 Whiting, 131 S. Ct. at 1973.

103 Id. at 1971.

${ }^{104}$ Id. at $1984-85$.

105 Colorado, Georgia, and Oklahoma, for example, have also passed similar laws. See H.B. 06-1343 § 1, 65th Gen. Assemb., 2d Reg. Sess. (Colo. 2006); S.B. 529 §2, 2006 Gen. Assemb., Reg. Sess. (Ga. 2006); H.B. $1804 \S \S 7,9,51$ st Leg., 1 st Reg. Sess. (Okla. 2007); see also Darcy M. Pottle, Federal Employer Sanctions as Immigration Federalism, $16 \mathrm{MiCH}$. J. RACE \& L. 99, 129-30 (2010).

${ }^{106}$ See Letter Brief of the Appellant City of Hazleton on Remand, in Light of the Supreme Court's Decision in Chamber of Commerce v. Whiting, 131 S. Ct. 1968 (2011) at 14, Lozano v. City of Hazleton, 620 F.3d 170 (3d Cir. 2011) (No. 07-3531).

107 See Arizona v. United States, 132 S. Ct. 2492 (2012).

${ }^{108}$ See id. at $2504-05 ;$ cf. Whiting, $131 \mathrm{~S}$. Ct. at 1987-89. 
whom it penalizes (employers) and whom it does not (workers), has farreaching implications for the IIRA lawsuits. The Arizona ruling suggests that in the IIRA context, as in the employment context, the absence of action by the federal government does not allow state or local actors to take their own unilateral action designed to penalize immigrants or to enforce immigration laws or policies, for to do so would be to disrupt the delicate balance that Congress has struck within the complex federal scheme.

Under the new framework of immigration federalism, therefore, while there may be some room in the future for states to pass their own anti-unauthorizedworker "alienage" legislation akin to Arizona's LAWA that punishes employers, there is no broad authority for wider-ranging action against immigrants that exceeds the preexisting boundaries of the comprehensive federal framework. In the next Part, I discuss the likely effect of these new constraints on state action on existing or pending state and local immigrantexclusionary legislation.

\section{THE NEW IMMIGRATION FEDERALISM AND IMMIGRANT EXCLUSION}

The Supreme Court's recent immigration preemption doctrine effectively precludes states passing their own anti-unauthorized-immigrant "immigration" laws. Although some state legislators may fear that this curtailment of their lawmaking powers will herald a permissive era of amnesty and laissez-faire acceptance of undocumented immigrants, all available evidence suggests that the opposite is true. Under the Obama Administration, federal immigration authorities have carried out record numbers of deportations, with over 400,000 immigrants removed from the United States in 2009 and 2010, and with the Department of Homeland Security set to deport two million immigrants by 2014 -approximately the same number of immigrants who were deported in the 105 years from 1892 to 1997.109

Despite this extraordinary record of immigration enforcement activity, since President Obama took office, according to the National Conference of State Legislatures, a record number of immigration-related laws were passed by state governments, including thirty-seven pertaining to state participation in immigration enforcement. ${ }^{110}$ State engagement with the enforcement of federal

${ }^{109}$ According to ICE, there were 387,000 removals and 476,000 returns without a removal order in 2010. See Julia Preston, Latinos and Democrats Press Obama To Curb Deportations, N.Y. TIMES, Apr. 21, 2011, at A18.

110 See NAT'L CONF. OF STATE LEgISLATURES, 2010 IMMIGRATION-RELATED LAWS AND RESOLUTIONS IN THE STATES (2011), available at http://www.ncsl.org/documents/immig/ 2010ImmigrationReport.pdf (describing how states "enacted a record number of laws and resolutions addressing immigration issues in 2010" and noting that " $[t]$ hirty-seven laws passed in 19 states: Alabama, Arizona, California, Connecticut, Florida, Georgia, Illinois, Kansas, Louisiana, Maryland, Michigan, Oklahoma, Pennsylvania, South Carolina, South Dakota, Tennessee, Utah, Virginia and Wyoming.... These laws generally deal with 
immigration laws excluding individuals from entry to the United States is not a new phenomenon, 111 but state involvement grew exponentially in the early years of the twenty-first century. ${ }^{112}$ This growth involved a plethora of state laws authorizing direct enforcement of federal "immigration laws," whether under so-called $287(\mathrm{~g})$ agreements with ICE delegating authority to do so, ${ }^{113}$ or under independent state initiatives such as Arizona's S.B. 1070.114 At the same time a wide range of exclusionary "alienage" laws pertaining to the treatment of immigrants were introduced, limiting immigrants' access to housing, employment, or language, and effectively serving an indirect enforcement function. ${ }^{15}$

This Part of the Article discusses these various iterations of state and local immigrant-exclusionary rulemaking. It considers, in light of the new direction for immigration federalism, the continued vitality of state and local involvement in (1) expressly delegated direct enforcement, (2) independent direct enforcement, and (3) indirect enforcement measures that are undertaken both with and without delegation from the federal government. The Article contends that under the new immigration federalism, States' and localities' engagement in any form of independent direct enforcement has been strictly curtailed and that many indirect enforcement measures will no longer be permissible.

\section{A. Expressly Delegated Direct Enforcement}

Many states and localities are actively involved in the direct enforcement of federal immigration laws pursuant to an agreement with the federal authorities that delegates responsibility for the enforcement of such laws. ${ }^{116}$ The two primary vehicles by which the federal government has delegated direct

collaboration with federal law enforcement agencies, processes for immigrant detention, prevention of child abduction, and responsibilities of law enforcement officers.").

${ }^{111}$ For example, the former Alien Criminal Apprehension Program (ACAP), through which states worked with the federal government to apprehend immigrants convicted of serious crimes, was established in 1988 by the former INS. AM. IMMIGRATION COUNCIL, THE Criminal Alien Program (CAP): Immigration Enforcement in Prisons and Jails (updated Aug. 2013), http://www.immigrationpolicy.org/sites/default/files/docs/cap fact sheet 8-1_fin_0.pdf. In 2006, ACAP was consolidated into the Criminal Alien Program. Id.

$1 \overline{1}$ See NAT'L CONFERENCE OF STATE LEgISLATURES, IMMIGRATION REPORTS (20052010), available at http://www.ncsl.org/issues-research/immig/state-laws-related-to-immigr ation-and-immigrants.aspx.

113 See infra Part IV.A.

114 See Nicholas D. Michaud, From 287(G) to S.B. 1070: The Decline of the Federal Immigration Partnership and the Rise of State-Level Immigration Enforcement, 52 ARIZ. L. REV. 1083, 1114-16 (2010).

115 See Lindsay Nash, Expression by Ordinance: Preemption and Proxy in Local Legislation, 25 GEO. IMMIGR. L.J. 243, 259-65 (2011).

116 I have written elsewhere of the potential pitfalls inherent in delegated direct enforcement. See Stella Burch Elias, "Good Reason To Believe": Widespread Constitutional Violations in the Course of Immigration Enforcement and the Case for Revisiting LopezMendoza, 2008 WIS. L. REV. 1109, 1135-39. 
enforcement authority of immigration laws to state and local law enforcement agencies are (1) agreements under Section $287(\mathrm{~g})$ of the Immigration and Nationality Act and (2) agreements under ICE's "Secure Communities" Program. Section $287(\mathrm{~g})$ of the INA authorizes the Attorney General to enter into agreements with state and local law enforcement agencies, permitting designated officers to perform immigration law enforcement functions, pursuant to a Memorandum of Agreement, provided that these officers receive appropriate training and function under the supervision of ICE officers. ${ }^{117}$ The delegated authority includes the power to arrest and detain noncitizens for immigration violations, to investigate immigration violations, and to collect evidence and prepare immigration cases that will be brought before a federal immigration judge. ${ }^{118}$ As of this writing, ICE has entered into sixty-nine active $287(\mathrm{~g})$ agreements in twenty-four states and more than 1,240 state and local law enforcement officers have been trained by immigration officials. ${ }^{119}$ The Obama Administration, cognizant of widespread criticism of the existence and practical operation of $287(\mathrm{~g})$ agreements, ${ }^{120}$ introduced a number of reforms to the program. ${ }^{121}$ Nevertheless, some commentators still express profound concerns about its efficacy. ${ }^{122}$

ICE's Secure Communities Program is a relatively new initiative that was launched in 2008. ${ }^{123}$ Under the program, participating state and local law enforcement agencies submit arrestees' fingerprints to the Department of

117 See Illegal Immigration Reform and Immigrant Responsibility Act of 1996, 8 U.S.C. $\S 1357(\mathrm{~g})(2012)$ (adding section 287(g) to the Immigration and Nationality Act).

${ }^{118}$ Id.; see also Wishnie, State, supra note 19, at 1091-95. The role of state and local officers in evidence collection and assistance with immigration case preparation is particularly unusual because state officials have no power to bring cases before federal immigration judges.

${ }^{119}$ See Fact Sheet: Updated Facts on ICE's 287(g) Program, ICE [hereinafter ICE Fact Sheet], http://www.ice.gov/news/library/factsheets $/ 287 \mathrm{~g}$-reform.htm (last visited Oct. 13, 2013).

${ }^{120}$ See, e.g., Elias, supra note 116; Wishnie, State, supra note 19.

121 See ICE Fact Sheet, supra note 119.

122 See NAT'l ImMigration LAW CTR., STATEMENT OF tHE NATIONAL IMMIGRATION LAW CENTER HEARING ON "BORDER SECURITY AND ENFORCEMENT-DEPARTMENT OF HOMELAND SECURITY'S COOPERATION WITH STATE AND LOCAL LAW ENFORCEMENT STAKEHOLDERS" BEFORE THE HOUSE COMMITTEE ON HOMELAND SECURITY SubCOMMITTEE ON BORDER AND MARITIME SECURITY ON MAY 3, 2011, at 3-5 (2011), http://www.nilc.org/document.html? id=236; DHS OFFICE OF INSPECTOR GEN., THE PERFORMANCE OF 287(G) AGREEMENTS, OIG-10-63 (2010), available at www.dhs.gov/xoig/assets/mgmtrpts/OIG_10-3_Mar10.pdf; DHS OFFICE OF INSPECTOR Gen., The Performance of 287(G) AGreements Report Update, OIG-10-124 (2010), available at $\mathrm{http}: / / \mathrm{www}$. oig.dhs.gov/assets/Mgmt/OIG_10-124_Sep10.pdf; RANDY CAPPS ET al., Migration Policy Inst., Delegation and Divergence: A Study OF 287(G) STATE AND LOCAL IMMIGRATION ENFORCEMENT (2011), available at http://www.migrationpolicy. org/pubs/287g-divergence.pdf.

${ }^{123}$ See Secure Communities: A Fact Sheet, IMMIGR. POL'y CENTER (Nov. 29, 2011), $\mathrm{http}: / / \mathrm{www}$.immigrationpolicy.org/just-facts/secure-communities-fact-sheet. 
Homeland Security's immigration databases. ${ }^{124}$ ICE initially informed states and localities that they had the option to participate voluntarily in the program at any time, without the requirement of a Memorandum of Agreement with the federal government. ${ }^{125}$ Recent evidence suggests, however, that ICE presumes participation in the program, requiring states and localities that did not wish to automatically use the database to opt-out of Secure Communities. ${ }^{126}$ As of January 2013, the biometric-information-sharing component of the program was activated in 3,181 jurisdictions in all fifty states, and the District of Columbia with nationwide implementation of the entire Secure Communities initiative expected by December 2013.127 Although three states (Illinois, Massachusetts, and New York) as well as a number of cities sought to withdraw from the Secure Communities Program, ${ }^{128}$ it remains one of the most ubiquitous examples of immigrant-exclusionary immigration federalism.

The Arizona v. United States Court highlighted both $287(\mathrm{~g})$ agreements and access to the Secure Communities database as examples of permissible state involvement in immigration enforcement. ${ }^{129}$ The Court stressed that officers covered by $287(\mathrm{~g})$ agreements are formally subject to the Attorney General's direction and supervision. ${ }^{130}$ Such supervision was necessary, according to the Court, because of the inherent complexity of immigration law. ${ }^{131}$ The Court mentioned the written certification contained within $287(\mathrm{~g})$ agreements, which attests that state and local officers have received adequate training to carry out

${ }^{124} \mathrm{Id}$.

$125 \mathrm{Id}$.

126 See CTr. for Constitutional Rights et al., Preliminary Briefing Guide: NeWly RelEased DoCuMENTS Chronicle AgenCy's DeCEPTION ABOUt Opting-OUT OF "SECURE COMMUNITIES" Program (2011), available at www.ccrjustice.org/files/Uncoverthe-Truth-FOIA-Briefing-Guide-2-17-111.pdf.

127 See ICE SECURE COMMUNTTIES, ACTIVATED JURISDICTIONS (2013), available at http://www.ice.gov/doclib/secure-communities/pdf/sc-activated.pdf.

${ }^{128}$ See Julia Preston, Immigration Program Is Rejected by Third State, N.Y. TIMES, June 6, 2011, at A13; Peter H. Schuck, Op-Ed., Three States Short of a Secure Community, N.Y. TIMES, June 23, 2011, at A27.

${ }^{129}$ See Arizona v. United States, 132 S. Ct. 2492, 2506 (2012) (The "principal example" of permissible federal-state cooperation in immigration enforcement "is when the Attorney General has granted that authority to specific officers in a formal agreement with a state or local government. See $\S 1357(\mathrm{~g})(1)$."). The Secure Communities database is accessible via ICE's Law Enforcement Support Center ("LESC"), which operates " 24 hours a day, 7 days a week, 365 days a year" and provides, among other things, "immigration status, identity information and real-time assistance to local, state and federal law enforcement agencies." Law Enforcement Support Center, ICE, www.ice.gov/lesc/ (last visited Sep. 28, 2013). According to ICE, the LESC responded to more than one million requests for information in 2009 alone. Id. See generally Anil Kalhan, Immigration Policing and Federalism Through the Lens of Technology, Surveillance, and Privacy, 74 OHIO ST. L.J. (forthcoming December 2013).

${ }^{130}$ See Arizona, 132 S. Ct. at 2506 (citing $§ 1357(\mathrm{~g})(3)$ ).

${ }^{131}$ Id. 
the duties of an immigration officer. ${ }^{132}$ It suggested that such certification was further evidence of the efficacy of $287(\mathrm{~g})$ as a tool of directly delegated enforcement power. ${ }^{133}$

The Court described other statutorily specified circumstances in which state and local police officers might exercise immigration enforcement powers, subject to direct federal control, namely in the event of an "imminent mass influx of aliens off the coast of the United States," or in specific circumstances after consultation with the federal government, or in specific instances in which an individual has smuggled or harbored certain immigrants. ${ }^{134}$ According to the Court, the federal government could also permissibly delegate its immigration authority to state personnel acting in cooperation with federal immigration officers as part of a joint task force or providing operation support in the execution of a federal warrant. ${ }^{135}$ Similarly, it could delegate its authority to state officials to enable them to provide federal immigration officers access to detainees held in state facilities or to assist the federal government by responding to federal requests for information about immigrant detainees held in their custody. ${ }^{136}$ In other words, under the new immigration federalism regime, state actors proceeding under the direct supervision (variously construed) of federal immigration officers may continue to engage in immigration enforcement.

Shortly after the Court rendered its judgment in Arizona v. United States, the federal government revoked its existing Section $287(\mathrm{~g})$ agreements with seven separate Arizona law enforcement agencies. ${ }^{137}$ In so doing the administration stated that it did not intend for Arizona's immigration policies to become the Department of Homeland Security's policies. ${ }^{138}$ This turn of events suggests another potential consequence of the Supreme Court's reinvigorated immigration preemption doctrine-renewed confidence on the part of the federal government that it can and should crack down not just on independent

${ }^{132} I d$.

${ }^{133} \mathrm{Id}$.

${ }^{134} I d$. The Court cites to $\$ 1357(\mathrm{~g})(1), \S 1103(\mathrm{a})(10)$ (authority may be extended in the event of an "imminent mass influx of aliens off the coast of the United States"), \$1252(c) (authority to arrest in specific circumstance after consultation with the Federal Government), and \$1324(c) (authority to arrest for bringing in and harboring certain aliens).

135 See Arizona, 132 S. Ct. at 2507 (citing Dep'T OF HOMELAND SeC., Guidance on

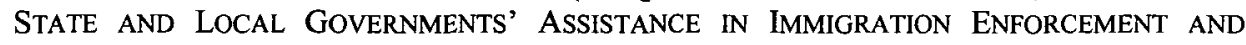
RELATED MATTERS 13-14 (2011), available at http://www.dhs.gov/guidance-state-andlocal-governments-assistance-immigration-enforcement-and-related-matters).

136 See id.; see also 8 U.S.C. § 1357(d) (2012).

${ }^{137}$ See Stephen Dinan, Homeland Security Suspends Immigration Agreements with Arizona Police, WASH. TIMES, June 25, 2012, http://www.washingtontimes.com/news/ 2012/jun/25/homeland-security-suspends-immigration-agreements-/?page=all.

${ }^{138}$ See Mike Ahlers, Official: Obama Administration Will Enforce Its Priorities, Not Arizona's, CNN (June 25, 2012, 8:31 PM), http://articles.cnn.com/2012-06-25/politics/ politics_immigration-administration-reaction_1_immigration-laws-law-enforcementimmigration-enforcement?_s=PM:POLITICS. 
state enforcement action but also on enforcement operations pursued, under color of federal delegation, by actors that cannot be relied upon to follow federal direction. Thus, while Section 287(g) agreements and use of Secure Communities continue to offer legally permissible avenues for state and local involvement in immigration enforcement, the federal government is evidently willing to exercise its discretion to prohibit states and localities from participating, should their stated goals and priorities depart significantly from those of the national government.

\section{B. Independent Direct Enforcement}

Arizona is just one state among many that have, during the last few years, considered and/or adopted independent state ordinances requiring law enforcement officers to question individuals about their immigration status or to arrest suspected undocumented immigrants. Although Arizona's S.B. 1070 has garnered the most media attention, five other states-Utah, Georgia, South Carolina, Alabama, and Indiana - enacted legislation that either mirrored or exceeded the Arizona statute. ${ }^{139}$ Moreover, at the time of writing, such legislation is still pending in five other states-Wisconsin, Illinois, Michigan, Pennsylvania, and Ohio. ${ }^{140}$ In the wake of the Court's ruling in Arizona $v$. United States the future of these state laws appears short-lived. It seems highly unlikely that any of these state laws, either enacted or pending, will survive in their current form following the Supreme Court's decision in Arizona v. United States.

Federal district courts in Arizona, Utah, Georgia, South Carolina, and Indiana enjoined the entry into force of the state immigration enforcement statutes in their jurisdictions, pending further judicial review. In Alabama, however, the Beason-Hammon Alabama Taxpayer and Citizen Protection Act ("H.B. 56") went into effect in late 2011.141 The Alabama statute, passed on

${ }^{139}$ See S.B. 529 §5(a)-(b), Gen. Assemb., Reg. Sess. (Ga. 2006); Complaint for Declaratory and Injunctive Relief at 33, Utah Coal. of La Raza v. Utah, 2011 WL 7143098 (D. Utah) (No. 11-CV-00401); see also SB 1070 Copycats, NAT'L CoUNCIL LA RAZA, http://www.nclr.org/index.php/issues_and_programs/immigration/policy_and_legislation_de tails/state_local_immigration_initiatives/arizona-related_legislative_developments (last visited Sep. 28, 2013). Many of these states adopted the Arizona model after consulting Kansas Secretary of State Kris Kobach, who advanced a "mirror image" theory of preemption. See Kobach, supra note 59, at 208.

${ }^{140}$ States that rejected or refused to consider such legislation in 2010 or 2011 are: California, Colorado, Florida, Iowa, Kansas, Kentucky, Louisiana, Maine, Mississippi, Nebraska, Nevada, New Hampshire, North Carolina, Oklahoma, South Dakota, Tennessee, Texas, Virginia, Washington, and Wyoming. See SB 1070 Copycats, supra note 139.

${ }^{141}$ H.B. $56 \S \S 1-7$, Leg., Reg. Sess. (Ala. 2011); see also Alan Gomez, Hispanics Feel Harassed Under Alabama's Immigration Law, USA TODAY, July 21, 2012, http://usatoday30.usatoday.com/news/nation/story/2012-07-21/arizona-immigration-lawalabama/56394360/1. 
June 9, 2011, and amended by H.B. 658 in May $2012,{ }^{142}$ is arguably the most aggressive of the state immigrant-exclusionary statutes. Among other things, H.B. 56 creates a state misdemeanor for failure to complete or carry an alien registration document, ${ }^{143}$ creates a state misdemeanor for engaging in paid employment without federal employment authorization, ${ }^{144}$ requires that Alabama public schools record students' immigration statuses, ${ }^{145}$ makes any business contract that an undocumented immigrant enters into unenforceable, ${ }^{146}$ and instructs police to check the immigration status of anyone they stop if they have "reasonable suspicion" that the person is an undocumented immigrant. 147 After Judge Blackburn of the Northern District of Alabama failed to enjoin the statute from entering into force on September 28, 2011,148 the United States Court of Appeals for the Eleventh Circuit, in two separate orders of October 14, 2011 and March 9, 2012, enjoined four subsections of the Act. ${ }^{149}$ However, Alabama's "show me your papers" provision, which, like Arizona's S.B. 1070 Section 2(B), requires a law enforcement officer to determine the citizenship and immigration status of a person stopped, detained, or arrested when "reasonable suspicion" exists that the person is unlawfully present in the United States, remains in effect. ${ }^{150}$ Section 18 of Alabama H.B. 56 also remains. Section 18 of the Alabama law provides that if a person is arrested for driving without a license, a "reasonable effort" shall be made to determine the citizenship of the driver, and if found to be unlawfully present in the United

142 Beason-Hammon Alabama Taxpayer and Citizen Protection Act, ALA. CODE § 3113-32 (2012).

${ }^{143}$ H.B. $56 \S 10$ (a) creates a criminal misdemeanor violation under Alabama law for willful failure to complete or carry an alien registration document if the person is in violation of 8 U.S.C. $\S 1304(\mathrm{e})$ or 8 U.S.C. $\S 1306$ (a) and is unlawfully present in the United States.

${ }^{144}$ H.B. $56 \S 11$ (a) creates a criminal misdemeanor for "a person who is an unauthorized alien to knowingly apply for work, solicit work in a public or private place, or perform work as an employee or independent contractor in this state."

${ }^{145}$ H.B. $56 \S 28$ (a) requires every public elementary and secondary school in Alabama to determine if an enrolling student was born outside the jurisdiction of the United States or is the child of an unlawfully present alien and qualifies for assignment to an English as second language class or other remedial program.

${ }^{146}$ H.B. $56 \S 27$ (a) bars Alabama courts from enforcing a contract to which a person who is unlawfully present in the United States is a party. H.B. $56 \S 27(\mathrm{~b})$ states that this section does not apply to contracts for lodging for one night, contracts for the purchase of food, contracts for medical services, or contracts for transportation for an alien to return to his or her country of origin. H.B. $56 \S 30$ makes it a felony for an alien not lawfully present in the United States to enter into a "business transaction" with the State of Alabama or any political subdivision thereof.

${ }^{147}$ H.B. $56 \S 12($ a), Leg., Reg. Sess. (Ala. 2011).

148 Hispanic Interest Coal. of Ala. v. Bentley, No. 5:11-CV-2484-SLB, 2011 WL 5516953, at *1-2 (N.D. Ala. Sept. 28, 2011), rev'd in part, Hispanic Interest Coal. of Ala. v. Governor of Ala., 691 F.3d 1236 (11th Cir. 2012).

149 Hispanic Interest Coalition of Alabama, 691 F.3d at 1241-42.

${ }^{150}$ H.B. 56 § 12(a), Leg., Reg. Sess. (Ala. 2011). 
States the driver shall be detained until prosecution or until he or she is handed over to federal immigration authorities. ${ }^{151}$

On July 6, 2012, immediately following the Supreme Court's decision in Arizona v. United States, the parties to United States v. Alabama ${ }^{152}$ filed briefings responding to the Court's ruling. Alabama conceded that under Arizona v. United States, the provisions of H.B. 56 creating new state misdemeanors for failure to carry an "alien registration document" and for working without federal employment authorization should be struck down immediately. ${ }^{153}$ The State argued, however, that its "show me your papers" provision should remain in effect because the Supreme Court had declined to enjoin Arizona S.B. 1070 Section 2(B) on which the Alabama statutory provision was modeled. ${ }^{154}$ Alabama further argued that Section 28 of H.B. 56, which requires public school administrators to ascertain the immigration status of newly enrolling students, should remain extant because S.B. 1070 contained no equivalent provision, and therefore the Supreme Court had not addressed the constitutionality of the Alabama rule. ${ }^{155}$ The United States Court of Appeals for the Eleventh Circuit preliminarily enjoined the provisions of the Act pertaining to the registration of schoolchildren but allowed the "show me your papers" provision to remain in force. ${ }^{156}$

The developments in Alabama presage the outcomes of the Utah, Georgia, South Carolina, and Indiana lawsuits opposing the implementation of the various independent immigrant-exclusionary laws. It seems clear that those provisions that mirror completely the sections of S.B. 1070 that the Supreme Court ruled preempted will be struck down immediately, while other nonequivalent provisions will be subjected to more searching review. In Indiana, for example, the state Attorney General has already conceded that key portions of S.B. 590, the state's "anti-illegal immigration law," are now preempted, ${ }^{157}$ most notably those provisions permitting state police officers to arrest

${ }^{151}$ Id. $\S 18$.

152 United States v. Alabama, 443 F. App'x 411, 415 (11th Cir. 2011).

153 See id.

${ }^{154}$ See Arizona v. United States, 132 S. Ct. 2492, 2510 (2012).

155 Immigrants' rights groups argue, however, that the provision creates a "de facto immigration registration process" for foreign-born schoolchildren-a field the Supreme Court found to have been entrusted exclusively to the federal government. See Apellants/Cross-Appellees' Reply/Response Brief at 9, Hispanic Interest Coal. of Ala. v. Bentley, 691 F.3d 1236 (11th Cir. 2012) (Nos. 11-14535, 11-14675).

${ }^{156}$ A separate lawsuit, Doe v. Hobson, was filed on February 7, 2013 seeking to enjoin the "blacklist" provision in Section 5 of H.B. 658, under the auspices of which the state of Alabama posted the names and whereabouts of "illegal immigrants" on a government website. See Complaint for Declaratory and Injunctive Relief at 9, Doe v. Hobson, No. 2:2013cv00079 (M.D. Ala. Feb. 7, 2013).

${ }^{157}$ Chris Sikich, Indiana Immigration Law Partially Unconstitutional, Says Attorney General, IND. STAR, July 31, 2012, http://www.indystar.com/article/20120731/NEWS/ 120731051/Indiana-immigration-law-partially-unconstitutional-says-attorney-general. 
individuals for suspected immigration violations. ${ }^{158}$ The State contends, however, that one provision of S.B. 590, which prohibits immigrants from using foreign-issued forms of identification, should not be preempted because there was no equivalent provision at issue in the Arizona lawsuit. ${ }^{159}$ Similarly, in Utah, the state Attorney General has conceded that some provisions of its H.B. 497 are now preempted, in particular those that create new immigrationbased state crimes. ${ }^{160}$ But, in Utah as in Indiana, the state continues to argue that those provisions of its immigrant-exclusionary law that are distinct from Arizona's S.B. 1070 should not be preempted. ${ }^{161}$ In South Carolina, the state Attorney General has also stated that, in light of Arizona v. United States, a number of the provisions of its independent immigration enforcement statute are preempted. ${ }^{162}$ There too, however, the state intends to continue to argue that at least one provision of its Act-one which creates a new state felony for anyone to knowingly harbor or transport an undocumented alien-is still valid, because it was not addressed by the Arizona $v$. United States Court. ${ }^{163}$ In each of these three instances, the federal courts where the lawsuits are pending have asked the parties to submit briefings, although there is no indication (as of this writing) as to when any ruling might issue in any of the three cases.

Commensurate with the new framework of immigration federalism embodied in the Arizona and Whiting cases, the federal circuit and district courts considering the continued validity of various provisions of the Indiana, South Carolina, and Utah independent enforcement statutes should find invalid any and all provisions that are analogous to those in Arizona's S.B. 1070, which were ruled preempted by the United States Supreme Court in Arizona v. United States. ${ }^{164}$ For, under the new post-Arizona framework of immigration

${ }^{158}$ Id. (" $[\mathrm{T}]$ he Supreme Court made it clear that state laws can't allow local officers to arrest people for immigration violations ....").

${ }^{159} \mathrm{Id}$.

160 See Utah Coal. of La Raza v. Herbert, No. 11-CV-401, 2011 WL 7143098 (D. Utah May 11, 2011); see also David Moreno, Shurtleff: Utah Immigration Law Won't Survive Intact, SALT LAKE TRIB., July 3, 2012, http://www.sltrib.com/sltrib/news/5441959478/immigration-law-state-court.html.csp (reporting comments that State Attorney General Shurtleff and Assistant Attorney General Philip Lott made at the Utah Immigration and Migration Commission meeting while briefing the twenty-seven-member board on the status of H.B. 497).

161 See Moreno, supra note 160 (Attorney General Shurtleff explained that he believes that the relevant difference between the two Acts is that Utah's provision requires legal status to be checked only after an arrest on a felony or a class A misdemeanor, i.e., in narrower circumstances that are thus distinct from S.B. 1070's broad mandate).

162 See Leigh Ann Caldwell, States Move Cautiously on Immigration After Supreme Court Ruling, CBS NEws (June 26, 2012, 6:33 PM), http://www.cbsnews.com/8301503544_162-57460997-503544/states-move-cautiously-on-immigration-after-supremecourt-ruling/; Noelle Phillips, U.S. Supreme Court Decision May Reverse Block on SC Law, HERALD, June 25, 2012, http://www.heraldonline.com/2012/06/25/4071166/us-supremecourt-upholds-police.html.

163 See generally Arizona v. United States, 132 S. Ct. 2492 (2012).

164 Id. at 2492. 
federalism, any state laws creating new state immigration-related crimes, mandating state officers to enforce federal immigration laws without direct delegation from the federal government, or requiring immigrants to produce special registration documents are prohibited. ${ }^{165}$ The Court's express rejection of the "mirroring" theory that was the cornerstone of all six states' independent enforcement statutes also precludes states from introducing other immigrationrelated regulations designed to "mirror" the federal statutory scheme. ${ }^{166}$ State laws that, similar to Arizona S.B. 1070 Section 2(B), require state officers in the course of a legitimate arrest or detention to inquire into individuals' immigration status appear set to survive in the short-term, although under the new framework of immigration federalism the long-term viability of such laws is questionable, at best. Immigrants' advocacy groups have already filed new suits arguing that these laws will likely lead to impermissible racial profiling, which may delay their implementation. ${ }^{167}$ Moreover, should the laws go into effect, "as applied" challenges will also surely be brought, with potentially farreaching effect. ${ }^{168}$ Under the new immigration federalism, therefore, the opportunity for states to engage in independent direct enforcement of immigration laws is substantially curtailed and may be restricted even further in the near future.

\section{Indirect Enforcement}

During the same period that some states and localities promulgated "attrition through enforcement" laws requiring the direct enforcement of federal immigration law by state agencies, other communities enacted provisions designed to enforce federal immigration law indirectly. Chief among these immigrant-exclusionary measures were the so-called "Illegal Immigrant Relief Acts" ("IIRAs"), the first of which was proposed in San Bernardino, California, in April 2006. ${ }^{169}$ These controversial ordinances, which have been passed in

165 See id.

166 See id.

167 See Sandra Hernandez, Arizona's "Show Me Your Papers" Provision Stuck in Legal Limbo, L.A. TIMES, Aug. 9, 2012, http://articles.latimes.com/2012/aug/09/news/la-arizona -immigration-police-20120809.

${ }^{168}$ The potential for racial profiling under such laws was demonstrated clearly following the entry into force of the Alabama statute. "The first eleven people arrested by Tuscaloosa police for violating the license not on person section of the Alabama law were two black females, four black males, one white female and four Hispanic males." Judith Browne Dianis, Supreme Court Decision on Arizona Immigration Law Could Still Lead to Racial Profiling, HuFFINGTON POST (June 28, 2012, 2:30 PM), http://www.huffingtonpost.com/ judith-browne-dianis/supreme-court-arizona-immigration_b_1630848.html.

${ }^{169}$ San Bernardino, Cal., Illegal Immigration Relief Act Ordinance (proposed Apr. 2006), available at http://www.ailadownloads.org/advo/SanBernardinoIllegallmmigration Ordinance.pdf. During the 1990s, some states passed what might be considered precursors to the IIRAs of the early twenty-first century. The most well-known of these state laws is California's Proposition 187, a ballot initiative which eliminated most public benefits for 
locations as diverse as Hazleton, Pennsylvania, ${ }^{170}$ Farmers Branch, Texas, ${ }^{171}$ Cherokee County, Georgia, ${ }^{172}$ and Escondido, California, ${ }^{173}$ have been the subject of intensive media scrutiny and long-running lawsuits, and typically penalize landlords for renting housing to undocumented immigrants, sanction employers for hiring undocumented workers, and/or include provisions designating English as the sole official language of the community. ${ }^{174}$ In so doing, they function as indirect enforcement mechanisms, excluding the undocumented from the local polity and thereby encouraging their migration elsewhere. ${ }^{175}$ As I discussed supra, in the aftermath of the Supreme Court's 2011 ruling in Chamber of Commerce v. Whiting, ${ }^{176}$ the future of such ordinances appeared uncertain. However, with the Supreme Court's clarification of its immigration federalism doctrine in Arizona v. United States, ${ }^{177}$ these immigration exclusionary ordinances are incompatible with the new framework of immigration federalism and are therefore constitutionally invalid. The Hazleton, Pennsylvania and Farmers Branch, Texas, lawsuits provide illustrative examples of the fate of all such provisions.

Hazleton, Pennsylvania was the first city in the United States to pass a comprehensive IIRA.178 The Hazleton ordinances focused initially on preventing landlords from renting apartments to undocumented immigrants by requiring landlords to check potential tenants' occupancy permits issued by the city indicating the potential renter's U.S. citizenship or other lawful

unauthorized immigrants and forbade their attendance at public schools. Rigel C. Oliveri, Between a Rock and a Hard Place: Landlords, Latinos, Anti-illegal Immigrant Ordinances, and Housing Discrimination, 62 VAND. L. REV. 55, 59 (2009); 1994 Cal. Legis. Serv. Prop. 187 (West) (approved Nov. 8, 1994), overturned in significant part by League of United Latin Am. Citizens v. Wilson, 908 F. Supp. 755, 786-87 (C.D. Cal. 1995); see Nash, supra note 115 .

${ }^{170}$ See Hazleton, Pa., Ordinance 2006-18 $\S 5$, 7.B (2006) (prohibiting landlords from harboring unlawful immigrants).

${ }^{171}$ Farmers Branch, Tex., Ordinance $2903 \S 3(2)$ (May 12, 2007) (“The owner and/or property manager shall require as a prerequisite to entering into any lease or rental arrangement, including any lease or rental renewals or extensions, the submission of evidence of citizenship or eligible immigration status for each tenant family ....").

172 Cherokee County, Ga., Ordinance 2006-003 $§ 18-503$ (a) (Dec. 5, 2006) (stating that "to let, lease, or rent" or "suffer or permit the occupancy" of a dwelling unit by an "illegal alien" is prohibited and "shall also be deemed to constitute harboring").

${ }^{173}$ Escondido, Cal., Ordinance 2006-38 $\S 1(3), 16 \mathrm{E}-1$ (Oct. 18, 2006) (declaring it unlawful for the owner of a dwelling unit to "harbor" an "illegal alien" and defining "harboring" as "to let, lease, or rent a dwelling unit to an illegal alien" or "[t]o suffer or permit the occupancy of the dwelling unit by an illegal alien").

174 See Nash, supra note 115 , at 248,249 n.27.

${ }^{175}$ Id.

${ }^{176}$ Chamber of Commerce v. Whiting, 131 S. Ct. 1968, 1987 (2011).

177 Arizona v. United States, 132 S. Ct. 2492 (2012).

178 See Oliveri, supra note 169 , at 59-60. 
immigration status. ${ }^{179}$ Landlords who failed to comply with the terms of the Act and rented their properties to undocumented immigrants faced fines of up to $\$ 5,000$ per violation. 180 The Federal District Court for the Middle District of Pennsylvania enjoined enforcement of the Act, holding, inter alia, that it violated due process rights of tenants and landlords. ${ }^{181}$ The Third Circuit subsequently affirmed the District Court's ruling. ${ }^{182}$ In June 2011, however, the United States Supreme Court summarily vacated the Third Circuit's ruling and remanded the case for further consideration in light of the Court's holding in Chamber of Commerce v. Whiting. ${ }^{183}$ The United States Court of Appeals for the Third Circuit heard oral arguments in the case on August 15, 2012, and issued its ruling on July 26, 2013. ${ }^{184}$ The Third Circuit, relying heavily on the Supreme Court's Arizona opinion, ruled that the federal government's primacy in the sphere of "immigration law" preempted the Hazleton anti-immigrant and housing ordinances. 185

During the same week, the United States Court of Appeals for the Fifth Circuit, sitting en banc, reached the same conclusion in Villa at Parkside Partners v. City of Farmers Branch. ${ }^{186}$ Farmers Branch, a Dallas suburb, introduced three separate ordinances designed to prevent undocumented immigrants from renting homes within its city limits in 2006, 2007, and 2008. The latest iteration, which requires the city buildings inspector to "verify with the federal government" that every noncitizen renting a dwelling is "an alien lawfully present in the United States," was enjoined, on preemption grounds, by the federal district court and by a three-judge panel of the Fifth Circuit. ${ }^{187}$ The en banc panel heard oral arguments on September 19, 2012, and issued its

${ }^{179}$ See Hazleton, Pa., Ordinance 2006-18 $\S \S 5$, 7.B (2006) (prohibiting landlords from harboring unlawful immigrants); Hazleton, Pa., Ordinance 2006-13 $\S 7 \mathrm{~b}(1)(\mathrm{g})(2006)$ (requiring landlords to check potential tenants' occupancy permits issued by city indicating citizenship or lawful status). Hazleton's multiple ordinances also prohibited businesses from "knowingly... aiding and abetting illegal aliens," including the employment of unauthorized migrants and the provision of goods and services to a day labor center that does not verify the status of all clients. See Hazleton, Pa., Ordinance 2006-40 (Dec. 26, 2006) ("Illegal Immigration Relief Act Implementation Amendment," amending Ordinance 2006-18 by adding $\S 7$, "Implementation and Process"); Hazleton, Pa., Ordinance 2006-18 (Sept. 8, 2006) ("City of Hazleton Illegal Immigration Relief Act Ordinance" as amended); Hazleton, Pa., Ordinance 2006-13 (Aug. 15, 2006) (Tenant Registration Program ordinance).

180 Hazleton, Pa., Ordinance 2006-18 $\S 5,7 . B$.

${ }^{181}$ Lozano v. City of Hazleton, 496 F. Supp. 2d 477, 538 (M.D. Pa. 2007); see also Julia Preston, Judge Voids Ordinances on Illegal Immigrants: Says Restrictions Violated Due Process, N.Y. TIMEs, July 27, 2007, at A14.

182 Lozano v. City of Hazleton, 620 F.3d 170, 224 (3d Cir. 2010).

183 City of Hazleton v. Lozano, 131 S. Ct. 2958, 2958 (2011).

${ }^{184}$ Lozano v. City of Hazleton, No. 07-3531, 2013 WL 3855549, at *6 (3d Cir. July 26, 2013)

$185 \mathrm{Id}$.

186 Villas at Parkside Partners v. City of Farmers Branch, No. 10-10751, 2013 WL 3791664 , at *6, $* 27$ (5th Cir. July 22,2013 ).

${ }^{187}$ Id. at $* 3, * 27$. 
opinion on July 22, 2013.188 Once again, the Court of Appeals held that under the doctrinal parameters set forth by the Supreme Court in Arizona, the local ordinances interfered impermissibly with the federal government's immigrantexclusionary powers. 189

Under the new doctrinal framework for immigration federalism set forth by the Supreme Court in the Arizona and Whiting cases, the Third and Fifth Circuit panels had no choice but to strike down the Hazleton and Farmers Branch ordinances. Although the Hazleton and Farmers Branch IIRAs do not track the Court's Arizona ruling as directly as the Alabama and Indiana "copycat" immigration enforcement laws, the restrictions that both towns placed on renting homes arguably detract from the "harmonious whole" of the scheme for immigrant admission and exclusion, substituting local judgment for that of the federal government. Moreover, the Arizona Court, in holding Sections 3, 5(C), and 6 of S.B. 1070 preempted, counseled against any action that might constitute "harassment of some aliens... whom federal officials determine should not be removed." 190 Unlike the LAWA sanction of employers, which the Whiting Court held to be permissible "alienage" regulation, direct action against immigrant tenants is surely the kind of "harassment" of noncitizens contemplated in Arizona. Thus, these housing-related indirect enforcement initiatives, and others like them, are unquestionably foreclosed by the new postArizona framework for immigration federalism.

This is not to say that there are now no avenues remaining for states to enact indirect enforcement provisions. The immigration and welfare laws of 1996, for example, expressly delegated to the states authority to enact some indirect enforcement regulations, including those that prohibit access to public benefits. ${ }^{191}$ Other immigrant-exclusionary state laws, such as those pertaining to medical care, welfare benefits, or in-state tuition eligibility, have also been grounded in this express delegation. ${ }^{192}$ Such measures have proliferated in recent years, ${ }^{193}$ and, as in the direct enforcement context, may be permissible

188 See id. at *6.

189 See id. ("The Court's Arizona decision instructs our opinion today.").

190 Arizona v. United States, 132 S. Ct. 2492, 2506 (2012).

${ }^{191}$ See 8 U.S.C. $\$ 1612$ (b) (2012) (authorizing states to determine eligibility of certain immigrants for Medicaid, Temporary Assistance to Needy Families, and Title XX block grants); id. $\S 1622$ (a) (authorizing states to determine eligibility of certain immigrants for state public benefits programs).

${ }^{192}$ See, e.g., COLO. REV. STAT. $§ 24-76.5-103$ (2006) (requiring every "agency" or "political subdivision of the state" to "verify the lawful presence in the United States of each natural person 18 years of age or older who applies for state or local public benefits"); S.B. 529 § 9(a), (c), Gen. Assemb., Reg. Sess. (Ga. 2006).

193 For example, regulations denying lawfully present immigrants access to state healthcare programs. See N.J. ADMIN. CODE $\S 10: 78-3.2(e)$ (2013) (terminating FamilyCare eligibility for legal permanent residents who are in status for less than five years); Medicaid Communication No. 10-01 from John R. Guhl, Dir., N.J. Dep't of Human Servs., Div. of Med. Assistance \& Health Servs., to Cnty. Welfare Agency Dirs., at 1 (Mar. 2, 2010), available at http://www.state.nj.us/humanservices/dmahs/info/resources/medicaid/2010/10- 
because of the direct mandate granted by the federal government. Overall, however, under the Supreme Court's recent immigration preemption case law, the opportunity for anti-immigrant action is greatly reduced within the new framework of immigration federalism. The same cannot, however, be said of the opportunity for pro-immigrant state and local lawmaking, which I turn to in the next Part of this Article.

\section{THE NEW IMMIGRATION FEDERALISM AND IMMIGRANT INCLUSION}

State and local "alienage" laws designed to welcome, integrate, and include immigrants play an increasingly important, but hitherto underexplored role in U.S. immigration law and policy. While some states have developed exclusionary statutes and regulations pertaining to immigrants, especially undocumented immigrants, other states and localities-including individual localities within immigrant-exclusionary states-have promulgated laws designed to foster the inclusion and integration of all immigrants into their local communities. ${ }^{194}$ It is not possible to discuss in this Article all of the myriad inclusionary measures adopted in different locales throughout the United States. This Part therefore focuses on two examples of local and state immigrantinclusionary provisions that have proliferated since the mid-1990s: (1) so-called sanctuary laws, designating areas (usually cities) as "sanctuaries" from immigration enforcement and providing all residents, regardless of immigration status, with equal access to local governmental services; and (2) in-state tuition initiatives and other measures designed to provide immigrant youth with equal access to higher education. This Part argues that while the new immigration federalism curtails states' and localities' ability to engage in immigrantexclusionary lawmaking, it simultaneously creates opportunities for states and localities to promulgate laws designed to foster immigrant inclusion.

01_Program_Changes_For_NJ_FamilyCare_Parents_Caretakers.pdf (citing the "unprecedented financial crisis" as the reason for terminating legal permanent residents from the program).

${ }^{194}$ Peter Schuck suggests that this aspect of immigration federalism is often overlooked by commentators. See Peter Schuck, The Disconnect Between Public Attitudes and Policy Outcomes in Immigration, in DEBATING IMMIGRATION 17-31 (Carol M. Swain ed., 2007); see also Anil Kalhan, Immigration Enforcement and Federalism After September 11, 2001, in IMMIGRATION, INTEGRATION, AND SECURITY: AMERICA AND EUROPE IN COMPARATIVE PerSPECTIVE 183 (Ariane Chebel d'Appollonia \& Simon Reich eds., 2008) ("[N]on-U.S. citizens are ... [i]n some instances ... finding greater concern for rights and liberties in those locales than they have in Washington."). 


\section{A. Comprehensive Sanctuary Ordinances}

Since the late twentieth century, a number of American cities and towns have adopted "sanctuary laws." 195 These provisions-whether statutes, resolutions, ordinances, or executive orders-were initially designed to curtail state and local police from engaging in the enforcement of federal immigration laws, ${ }^{196}$ but they have subsequently evolved to encompass the provision of a number of services to immigrant communities (including the undocumented members of those communities) on par with those provided to U.S. citizen residents. ${ }^{197}$ Although sanctuary laws are unquestionably controversial, ${ }^{198}$ their evolution from a means of signaling expressive dissent from federal government policy to an integrated regulatory scheme for the inclusion of immigrants into their local polity ${ }^{199}$ is an integral component of the new immigration federalism. ${ }^{200}$

The sanctuary movement in the United States began in the late 1970s and grew during the $1980 \mathrm{~s}$, as churches and other affiliated organizations re-invoked the medieval privilege of "sanctuary" 201 or safe haven for nationals of Guatemala and El Salvador who faced deportation to countries riven by civil war. ${ }^{202}$ A number of cities, such as San Francisco, supported this movement by passing resolutions stating that asylum-seekers from Guatemala and El Salvador need not fear arrest and deportation within their jurisdictions. ${ }^{203}$ In time, these measures became increasingly generalized, evolving from a prohibition on immigration enforcement against Guatemalan and Salvadorian refugees and asylum-seekers, to a prohibition against discrimination by city officials on the basis of immigration status of those refugees and asylum seekers, and then to an

195 The city of Los Angeles, for example, has had some type of sanctuary policy since 1979 ; other major U.S. cities followed suit in the 1980s. See Pham, supra note 19, at 138295.

${ }^{196}$ See id. at 1383; see also Pratheepan Gulasekaram \& Rose Cuison Villazor, Sanctuary Policies \& Immigration Federalism: A Dialectic Analysis, 55 WAYNE L. REV. 1683, 1683-91 (2009).

${ }^{197}$ See Pham, supra note 19, at 1389; see also Jennifer Medina, New Haven Approves Program To Issue Illegal Immigrants IDs, N.Y. TIMES, June 5, 2007, at B6.

${ }^{198}$ See, e.g., Jesse McKinley, Immigrant Protection Rules Draw Fire: Prosecutors Defend Witness Policies, N.Y. TIMES, Nov. 12, 2006, at 22 (describing challenges by conservative legal groups and politicians to sanctuary ordinances in Chicago, Houston, Los Angeles, and San Francisco).

${ }^{199}$ This evolution does not, of course, preclude the current array of comprehensive sanctuary ordinances from also fulfilling a valuable dissent function-indeed, such ordinances continue to communicate a state's or municipality's dissatisfaction with federal immigration requirements.

200 See Bulman-Pozen \& Gerken, supra note 30, at 1259.

201 See generally KARL SHOEMAKER, SANCTUARY AND CRIME IN THE MidDLE AGES, 400-1500 (2011) (describing sanctuary protections in the western legal tradition).

202 See STEPHEN H. LEGOMSKY, IMMIGRATION AND REFugEE LAW AND POLICY 1206-07 (4th ed. 2005).

${ }^{203}$ See Rodriguez, supra note 7, at 600-01. 
eventual prohibition against any form of discrimination on the basis of immigration status against any immigrant individual. ${ }^{204}$ In the 1990 s and early twenty-first century, cities without ties to the original sanctuary movement of the 1970s and 1980s, such as Durango, Colorado 205 and Trenton, New Jersey, ${ }^{206}$ also began to enact ordinances prohibiting discrimination on the basis of immigration status, limiting disclosure of residents' immigration status by city authorities, and offering public services, including municipal identification cards, to undocumented migrants. To date, almost seventy different U.S. jurisdictions, ranging from the State of Alaska to the City of New Haven, Connecticut, have promulgated local rules prohibiting local police officers from inquiring into an individual's immigration status and preventing discrimination on the basis of immigration status. ${ }^{207}$

Commentators have offered a variety of different explanations for why so many cities have recently enacted sanctuary ordinances. One suggestion is that the sanctuary laws constitute a backlash against initiatives by federal Immigration Customs and Immigration Enforcement ("ICE") to co-opt local law enforcement officers to perform immigration functions. ${ }^{208}$ Indeed, many of the most trenchant critiques of the $287(\mathrm{~g})$ program have been employed to justify sanctuary ordinances. ${ }^{209}$ For example, the concern that $287(\mathrm{~g})$ agreements discourage immigrant communities from cooperating with police because individuals fear that they will be at risk of removal if they report crimes is countered by the suggestion that sanctuary ordinances actively encourage immigrant victims of crime to come forward. ${ }^{210}$

Another explanation for the increase in sanctuary ordinances is that ICE home and workplace raids during the later years of the Bush Administration alienated sufficient numbers of U.S. citizens to create a groundswell of popular support for sanctuary initiatives. ${ }^{211}$ There is limited empirical evidence to support this proposition, although during the period from 2006 to 2009, reports

${ }^{204}$ See id. at 601 n.145; S.F., CAL., ADMIN. CODE $§ 12$ H.2(c) (2005) (approved Oct. 24, 1989).

${ }^{205}$ See Laura Sullivan, Enforcing Nonenforcement: Countering the Threat Posed to Sanctuary Laws by the Inclusion of Immigration Records in the National Crime Information Center Database, 97 CALIF. L. REV. 567, 576-77 (2009).

${ }^{206}$ Kirk Semple, In Trenton, Issuing IDs for Illegal Immigrants, N.Y. TIMES, May 17, 2010, at A17, A19.

207 See NAT'L IMMIGRATION LAW CTR., supra note 11.

${ }^{208}$ Cristina Rodriguez, for example, suggests that many sanctuary resolutions served as "direct legislative and administrative responses to the federal government's expanding efforts to enlist state and local police voluntarily in the enforcement of immigration laws in the years after the attacks of September 11, 2001." Rodriguez, supra note 7, at 601 .

209 See Michaud, supra note 114, at 1101 (noting that "[v]arious cities and agencies have assumed this logic in their adoption of 'sanctuary laws' and policies").

210 Id.

${ }^{211}$ See Elias, supra note 116, at 1127 n.98 (describing criticism of ICE Enforcement operations including "Return To Sender," "Cross-Check," "Community Shield," and "Wagon-Train"). 
of violations of immigrants' and citizens' constitutional rights during ICE raids, in particular the negative impact on U.S. citizen children, received extensive negative media coverage ${ }^{212}$ and prompted a congressional investigation into the raids. ${ }^{213}$ It is thus certainly possible that the sanctuary ordinances of the early twenty-first century evolved in part as a reaction against aggressive federal enforcement initiatives.

An alternative, and perhaps complementary, explanation for the rise of sanctuary laws as an expression of immigration federalism lies in the increasingly sophisticated roles and identities of "sanctuary cities" themselves and of the individuals who constitute them. In 1979, when the City of Los Angeles adopted Special Order 40, its sanctuary ordinance, it claimed that it was doing so because of "social issues involving problems of health, welfare, education, housing, and employment which are related to the assimilation of large numbers of persons with varied cultural heritages." 214 This phenomenon, identified by city officials in Los Angeles in 1979,215 in San Francisco in 1985,216 in Detroit in $2002,{ }^{217}$ and in Philadelphia in 2003, ${ }^{218}$ underscores the potential of the city to serve both as a vehicle for immigrant integration across many strata and as a locus for the protection of immigrants' individual rights. ${ }^{219}$ Indeed, Cristina Rodriguez argues that "global cities" such as New York, Los Angeles, and Chicago are particularly well placed to serve as "ports of entry"220

212 See Nina Bernstein, Promise of ID Cards Is Followed by Peril of Arrest for Illegal Immigrants, N.Y. TIMES, July 23, 2007, at B1, B5.

${ }^{213}$ On February 13, 2008, the House Subcommittee on Immigration, Citizenship, Refugees, Border Security, and International Law held a hearing on "Problems with ICE Interrogation, Detention, and Removal." Problems with ICE Interrogation, Detention, and Removal Procedures: Hearing Before the H. Subcomm. on Immigration, Citizenship, Refugees, Border Sec., and Int'l Law of the H. Comm. on the Judiciary, 110th Cong. (2008) (statement of Gary E. Mead, Deputy Dir., Office of Det. \& Removal Operations).

${ }^{214}$ L.A., Cal., Special Order 40, at 1 (Nov. 27, 1979).

215 Id.; NAT'L IMMIGRATION LAW CTR., supra note 11, at 2.

${ }^{216}$ City of S.F., Cal., Bd. of Supervisors Res. 389-02 (June 3, 2002), available at http://www.sfbos.org/index.aspx?page=2883; S.F., Cal., Ordinance 274-07 (Nov. 20, 2007), available at $\mathrm{http}: / / \mathrm{www}$. sfbos.org/index.aspx?page $=2957$ (authorizing County Clerk to issue municipal identification cards upon request to residents).

217 Detroit, Mich., Local Res. To Protect Civil Liberties (Dec. 6, 2002), available at http://www.aclu.org/national-security/detroit-resolution.

218 NAT'L IMMIGRATION LAW CTR., supra note 11, at 17.

219 See Seyla Benhabib, Transformations of Citizenship: Dilemmas of the NATION StaTE IN THE ERA OF GlobaLizATION 62-63 (2001); Judith Resnik, Law's Migration: American Exceptionalism, Silent Dialogues, and Federalism's Multiple Ports of Entry, 115 YALE L.J. 1564, 1564 (2006) ("America's federalist structure also serves as a path for the movement of international rights across borders."); see also Richard T. Ford, City-States and Citizenship, in CITIZENSHIP TODAY: GlOBAL PERSPECTIVES AND PRACTICES 209, 226-27 (T. Alexander Aleinikoff \& Douglas Klusmeyer eds., 2001) (discussing the city as a supplemental site of citizenship because its cosmopolitanism and limited geographical scope promotes "identity and inspire[s] esprit de corps").

220 Resnik, supra note 219 , at 1564 . 
for individual immigrants' rights because they have become focal points for "immigrant diasporas of various types and from around the world" who are drawn to such cities in search of employment. ${ }^{221}$

Professor Rodriguez's argument explains, to some extent, the sanctuary laws adopted by cities like New York that have economies that are dependent upon immigrant workers, including undocumented laborers. ${ }^{222}$ It may also account, in part, for the promulgation of sanctuary laws in locales such as New Haven, Connecticut or Cambridge, Massachusetts, which are home to major universities and are therefore more likely to be ports of entry for diverse immigrant groups. ${ }^{223}$ The development of sanctuary laws in towns like Aztec, New Mexico, ${ }^{224}$ Durango, Colorado, ${ }^{225}$ and Ashland, Oregon, ${ }^{226}$ is less easily explained in these terms, however, because they are not traditional ports of entry to the United States. These smaller cities often have smaller immigrant communities, composed primarily of migrants who have followed family members or neighbors from their hometown who previously immigrated to the United States. ${ }^{27}$ The proliferation of sanctuary ordinances in cities of varying sizes suggests that global reach is not the only determinant of whether or not a locale will adopt a sanctuary law, 228 but rather merely one factor among others, including (but not limited to) the diversity of the city's population, the degree of political support for immigrant communities (either a city's own immigrants or in solidarity with others elsewhere), and the established ties between documented and undocumented immigrant groups. ${ }^{229}$

${ }^{221}$ Rodriguez, supra note 7, at 577; see Resnik, supra note 219.

222 See Comprehensive Immigration Reform: Examining the Need for a Guest Worker Program: Hearing Before the S. Comm. on the Judiciary, 109th Cong. 5 (2006) (statement of Michael R. Bloomberg, Mayor, N.Y.C.), available at http://www.gpo.gov/fdsys/pkg/ CHRG-109shrg30254/pdf/CHRG-109shrg30254.pdf ("Although they broke the law by illegally crossing our borders or overstaying their visas . . . our City's economy would be a shell of itself had they not, and it would collapse if they were deported.").

223 See Michael Castagna et al., Securing Non-Citizen Voting Rights: Determining the Feasibility of ENABling Legislation in MASSAChuSETts 1-2 (2005); Caitlin Carpenter, New Haven Opts To Validate Its Illegal Residents, Christian SCI. MONITOR, July 17, 2007, http://www.csmonitor.com/2007/0717/p02s01-ussc.html.

224 Aztec is located in the northwestern corner of the state, not near the U.S./Mexico border. See LiSA M. SEghetTI, CONG. ResearCh SERVICE, RL32270, ENFORCING IMMIGRATION LAW: THE ROLE OF STATE AND LOCAL LAW ENFORCEMENT 26 n.85 (2006), available at trac.syr.edu/immigration/library/P1072.pdf.

225 Durango, Colo., City Council Res. No. R-2004-40 (July 6, 2004).

${ }^{226}$ See Sullivan, supra note 205, at 573; NAT'L IMMIGRATION LAW CTR., supra note 11 , at 16 .

${ }^{227}$ See JENNIFER GORDON, SUBURBAN SWEATSHOPS: THE FIGHT FOR IMMIGRANT RIGHTS 32-39 (2005); Alejandro Portes \& Ruben G. Rumbaut, IMMigrant AMERICA 24-26 (2006).

${ }^{228}$ According to Huyen Pham, over twenty such laws were passed in a variety of differently sized towns and cities. See Pham, supra note 19, at 1383.

${ }^{229}$ See Rose Cuison Villazor, What Is a "Sanctuary"?, 61 SMU L. REV. 133, 148 (2008). The views of documented immigrants towards the undocumented vary wildly from 
Moreover, during the summer of 2012, both "vertical" and "horizontal" uncooperative federalism concerns appear to have animated some locales' decisions to bolster existing sanctuary measures. ${ }^{230}$ On July 9, 2012, during the same week that the Governors and Attorneys General of Arizona, Alabama, Utah, Indiana, Georgia, and South Carolina emphasized their continued commitment to "attrition through enforcement" measures, Chicago Mayor Rahm Emanuel announced that he would propose a city-wide ordinance barring Chicago police officers from turning over undocumented immigrants to federal agents, provided the immigrants had no serious criminal convictions or outstanding criminal warrants. ${ }^{231}$ Mayor Emanuel's announcement coincided with both increased media scrutiny of Arizona-style independent enforcement laws and with federal criticism of an existing Cook County, Illinois sanctuary ordinance. ${ }^{232}$ During the same week, the California Senate passed the Trust Act, a bill designed to limit the reach of Secure Communities on a statewide level..$^{233}$ The Act precluded state officers from collecting information about noncriminal immigrants. Significantly, advocates for the bill explicitly stressed its signaling role within the context of the disparity between immigrant-exclusionary and immigrant-inclusionary states. "Arizona and its governor may view all immigrants as criminals ... but in California we have a different view," explained one of the bill's proponents. ${ }^{234}$ Furthermore, when California Governor Jerry Brown vetoed the Trust Act in October 2012, the Police Chief of Los Angeles, Charlie Beck, immediately responded by announcing that the City would no longer honor requests from ICE to turn over nonviolent immigrant offenders with minor criminal records, in effect limiting the applicability of Secure Communities within Los Angeles City limits. ${ }^{235}$ This chain of inter-state and intra-state reactions demonstrates the potential "hydraulics" of immigration regulation reform, to borrow Samuel Issacharoff and Pamela Karlan's metaphor for campaign finance reform. ${ }^{236}$ With

state to state and within states and localities. See, e.g., Lacey, supra note 26, at 20 (describing deep divisions among Arizona's Latino community, including first generation immigrants, over S.B. 1070).

230 See Bulman-Pozen \& Gerken, supra note 30, at 1271-72.

231 Preston \& Yaccino, supra note 24, at A14 ("'If you have no criminal record, being part of a community is not a problem for you,' Mr. Emanuel said, speaking at a high school library in Little Village, a Latino neighborhood. 'We want to welcome you to the city of Chicago."').

232 Oversight of the U.S. Department of Homeland Security: Hearing Before the S. Comm. on the Judiciary, 112th Cong. 16 (2012) (Statement of Janet Napolitano, Sec'y, Dep't of Homeland Sec.).

233 Esquivel, supra note 23, at AA1.

${ }^{234}$ Id. (quoting Chris Newman, legal director for the National Day Laborer Organizing Network).

${ }^{235}$ See lan Lovett, Los Angeles To Cease Transferring Immigrants, N.Y. TIMES, Oct. 5, 2012 , at A14.

${ }^{236}$ Cf. Samuel Issacharoff \& Pamela S. Karlan, The Hydraulics of Campaign Finance Reform, 77 TEX. L. REV. 1705, 1708 (1999) (comparing political money to water, in that it 
immigration, as with campaign finance, the impetus for reforming the status quo inevitably "has to go somewhere" 237 and in this instance moved from the national stage, to the state level, and ultimately to the local level.

Sanctuary legislation restricting state law enforcement of federal immigration law has thus become an accepted part of the legislative landscape in Alaska, California, Maine, Illinois, Massachusetts, New Mexico, New York, and Oregon, ${ }^{238}$ despite provisions in the 1996 federal immigration and welfare acts expressly prohibiting local governments from preventing their employees from voluntarily conveying information regarding an individual's immigration status to federal authorities. ${ }^{239}$ Challenges to state and local sanctuary laws, based on the relevant clauses of the Illegal Immigration Reform and Immigrant Responsibility Act ("IIRIRA") and the Welfare Reform Act have, however, been unsuccessful. In Sturgeon $v$. Bratton, ${ }^{240}$ for example, Californian antiimmigrant activists sought to enjoin Los Angeles's Special Order 40, discussed supra, which precludes officers from inquiring into individuals' immigration statuses or arresting individuals on the suspicion of having committed immigration-related crimes. ${ }^{241}$ Sturgeon, the plaintiff, argued that the Los Angeles Order was preempted by Section 642 of IIRIRA, which provides that governments may not prevent their employees from "[e]xchanging such information with any other Federal, State, or local government entity." 242 The California Court of Appeal, however, held that S.O. 40 was not preempted under the doctrines of field, conflict, or obstacle preemption, because the Order governed police actions and arrests, not the sharing with the federal government

"has to go somewhere" and "never really disappears into thin air" while also being "part of a broader ecosystem").

${ }^{237}$ Id.

${ }^{238}$ As discussed supra Part IV.A, California, Illinois, Massachusetts and New York withdrew this year from ICE's "Secure Communities" Program. See Preston, supra note 128 , at A13. Previous state measures limiting state enforcement of federal immigration restrictions include: OR. REV. STAT. $\$ 181.850$ (1) (2005); H.R.J. Res. 22, 23d Leg., 1st Sess. (Alaska 2003); Governor of New Mexico, Bill Richardson, Exec. Order No. 2005-019, Clarifying Victim and Witness Protections in New Mexico (Apr. 7, 2005); Exec. Order No. 2005-019 (N.M. Apr. 7, 2005), available at http://nmdigital.contentdm.oclc.org/cdm/single item/collection/p267801 colls/id/2129/rec/5.; Exec. Order No. 34 FY 04/05 (Me. Feb. 28, 2005) (clarifying Exec. Order No. 13 FY 04/05 (Me. Apr. 9, 2004) (concerning access to state services for all Maine residents)), available at http://www.maine.gov/tools/whatsnew/ index.php?topic $=$ Gov_Executive_Orders $\& i d=21373 \& v=$ Article.

${ }^{239}$ Section 434 of the Welfare Reform Act, 8 U.S.C. $\$ 1644$ (2012), provides that "no State or local government entity may be prohibited, or in any way restricted, from sending to or receiving from the Immigration and Naturalization Service information regarding the immigration status, lawful or unlawful, of an alien in the United States," and section 642 of the Illegal Immigration Reform and Immigrant Responsibility Act, 8 U.S.C. § 1373(b)(3) (2012), provides that governments may not prevent their employees from "[e]xchanging such information with any other Federal, State, or local government entity."

240 Sturgeon v. Bratton, 95 Cal. Rptr. 3d 718, 722 (Ct. App. 2009).

241 See supra note 214 and accompanying text.

2428 U.S.C. $\$ 1373($ b)(3). 
of any information that may be obtained during the course of such actions. ${ }^{243}$ The Court held that Section 642 demonstrated Congress's intent to ensure the voluntary flow of information from states and localities to ICE, and nothing further. ${ }^{244}$ The Act does not prohibit states and localities from instructing their officers to refrain from obtaining information about immigrants' statuses, and thus federal law did not preempt the L.A.P.D. order. ${ }^{245}$

At the heart of the California Court of Appeal's ruling in Sturgeon is a conception of the L.A.P.D. "don't ask" sanctuary policy as a regulation of local police conduct, rather than any kind of local attempt at immigration rulemaking. This seems accurate because, as Bill Ong Hing has argued, the twin goals of almost all sanctuary policies are (1) to promote public safety (by encouraging immigrant victims of crime to come forward) and (2) to preserve economic resources (by limiting police expenditures to non-immigration-related crimes and not expending personnel time on making immigration-related inquiries). ${ }^{246}$ Thus, as Professor Hing suggests, sanctuary ordinances serve a legitimate state or local purpose and do not "in and of themselves" regulate immigration. ${ }^{247}$ Sanctuary ordinances are, therefore, conceptually distinct from immigrantexclusionary state immigration enforcement statutes, because, while the former involve states and localities deciding how to marshal their resources to investigate violations of their own criminal laws (without reference to immigration regulation), the latter involve states creating their own exclusionary immigration laws. 248

Under the new framework of immigration federalism created by Arizona $v$. United States and Chamber of Commerce v. Whiting, it is completely permissible for states and localities to make choices about the allocation of their own resources in ways designed to benefit their residents in the regulation of employer actions, in the investigation of crimes, and in the provision of services to local communities. ${ }^{249}$ In contrast, it is impermissible for states and localities

243 Id.

244 Sturgeon, 95 Cal. Rptr. 3d at 731-33.

245 Id.

246 Bill Ong Hing, Immigration Sanctuary Policies: Constitutional and Representative of Good Policing and Good Policy, 2 U.C. IRVINE L. REV. 247, 253-60 (2012).

${ }^{247}$ Id:; see also Public Safety and Civil Rights Implications of State and Local Enforcement of Federal Immigration Laws: J. Hearing Before the Subcomm. on Immigration, Citizenship, Refugees, Border Sec., \& Int'l Law and the Subcomm. on the Constitution, Civil Rights, \& Civil Liberties of the H. Comm. on the Judiciary, 111 th Cong. 83-84 (2009) (testimony of George Gascón, Chief, Mesa Police Dep't, Mesa, Ariz.).

${ }^{248}$ See Lynn Tramonte, Immigration Policy CtR., Debunking the Myth of SANCTUARY CITIES 3 (2011), available at http://www.immigrationpolicy.org/sites/de fault/files/docs/Community_Policing_Policies_Protect_American_042611_update.pdf;

NAT'L IMMIGRATION FORUM, IMMIGRATION LAW ENFORCEMENT BY STATE \& LOCAL POLICE 2-3 (2007), available at http://www.immigrationforum.org/images/uploads/BackgrounderStateLocalEnforcement.pdf. See generally DAVID A. HARRIS, GOOD COPS: THE CASE FOR PREVENTIVE POLICING 14-25 (2005).

${ }^{249}$ See Arizona v. United States, 132 S. Ct. 2492, 2503, 2505, 2507 (2012). 
to create their own additional laws that serve as indirect proxies for federal immigration enforcement. 250

The Department of Justice has also acknowledged this important distinction, which has evidently informed its litigation strategy and policy priorities for several years. As Tracy Schmaler, a spokeswoman for the Attorney General, explained at the time that the Arizona suit was filed: "There is a big difference between a state or locality saying they are not going to use their resources to enforce a federal law, as so-called sanctuary cities have done, and a state passing its own immigration policy that actively interferes with federal law." 251 In 2007, during the Bush Administration, the Inspector General formally determined that the "don't ask" sanctuary policies of New York City, San Francisco, and the State of Oregon do not conflict with federal law. ${ }^{252}$ That determination has stood, even while the Obama Department of Justice has vigorously sought to enjoin the state immigration enforcement laws in Arizona, Alabama, Utah, Indiana, Georgia, and South Carolina on the grounds that such legislation is preempted. ${ }^{253}$ Moreover, the federal government's current policy of under-enforcement with respect to certain "low-risk" classes of undocumented immigrants tracks, in many ways, the determinations made by "sanctuary city" police personnel. 254

As Kit Johnson argued recently, state and local lawmaking to date has been "politically lopsided against immigrants." 255 True, more states have introduced immigrant-exclusionary measures in recent years than have introduced immigrant-inclusionary provisions, ${ }^{256}$ but as the lower federal courts rule on the pending immigrant-exclusionary statute and ordinance cases there is, for the first time, a meaningful opportunity for the balance to tip in the other direction. Indeed, early indications suggest that this is exactly what is happening in the

250 See Chamber of Commerce v. Whiting, 131 S. Ct. 1968, 1987 (2011).

${ }^{251}$ Stephen Dinan \& Kara Rowland, Justice: Sanctuary Cities Safe from Law, WASH. TIMES, July 15, 2010, at A4.

252 See U.S. DEP'T OF JUSTICE, COOPERATION OF SCAAP RECIPIENTS IN THE REMOVAL OF CRIMINAL ALIENS FROM THE UNITED STATES 23-24 (2007), available at http://www.justice.gov/oig/reports/OJP/a0707/final.pdf. See generally Ignatius Bau, Cities of Refuge: No Federal Preemption of Ordinances Restricting Local Government Cooperation with the INS, 7 LA RAZA L.J. 50, 50-53 (1994).

253 See discussion supra Part IV.A-B.

${ }^{254}$ See Memorandum from John Morton, Dir., U.S. Immigration \& Customs Enforcement, to Pers. of U.S. Immigration \& Customs Enforcement (June 17, 2011), available at http://www.ice.gov/doclib/secure-communities/pdf/prosecutorial-discretionmemo.pdf; Consideration of Deferred Action for Childhood Arrivals Process, U.S. CITIZENSHIP \& IMMIGR. SERVICES, http://www.uscis.gov/childhoodarrivals (last visited Oct. 1, 2013) [hereinafter U.S. CITIZENSHIP \& IMMIGR. SER VICES].

255 See Johnson \& Spiro, supra note 92, at 111.

256 See Daniel C. Vock, With Feds Stuck, States Take on Immigration, STATELINE, Dec. 13, 2007, http://www.pewstates.org/projects/stateline/headlines/with-feds-stuck-states-takeon-immigration-85899387478 (last updated Dec. 17, 2007, 1:30 PM) (noting that "laws restricting the rights or benefits of illegal immigrants outnumbered laws benefiting them by a 2-1 ratio"). 
post-Arizona legislative landscape, as state and local immigrant-inclusionary rulemaking has begun to outstrip immigrant-exclusionary regulations. ${ }^{257}$ This increasing vitality of state and city sanctuary laws, and related laws guaranteeing provision of a variety of services to the undocumented, ${ }^{258}$ combined with a new bipartisan impetus for comprehensive immigration reform, suggest that sanctuary ordinances will endure, and perhaps even flourish, within the new immigration federalism framework. The same can be said of state regulations designed to ameliorate immigrant students' access to education.

\section{B. Education Access Legislation}

On June 15, 2012, the thirty-year anniversary of Plyler v. Doe, ${ }^{259}$ the Department of Homeland Security ("DHS") announced its "Deferred Action for Immigrant Youth" ("DACA") initiative. 260 Under this program, set forth in a memorandum, the DHS exercises its prosecutorial discretion to grant "deferred action" for a renewable period of two years to undocumented immigrants under thirty-one years of age who by June 15, 2012: (1) entered the United States when they were less than sixteen years old; (2) have lived continuously in the United States for at least five years; (3) are in school, are high school graduates, or are military veterans in good standing; and (4) have no criminal record. ${ }^{261}$ The young immigrant recipients of DACA are able to obtain employment authorization, and thus Social Security numbers, driver's licenses (in some states), and other documentation. ${ }^{262}$ Opponents of immigration reform attempted to halt DACA by filing a lawsuit claiming that it constituted an impermissible use of executive powers to subvert the INA-but the challenge

${ }^{257}$ See, e.g., NAT'L IMMIGRATION LAW CTR., supra note 11, at 11-13.

${ }^{258}$ These services include access to public amenities in New Haven, housing in San Francisco, or medical care in New York. See Schuck, supra note 25, at 389 (noting that the anticipated "race to the bottom" has not occurred and instead numerous states, including those with large immigrant populations, have restored benefits on the state level that had been lost at the federal level, in some instances providing new benefits, including Medicaid); see also Sarah Kershaw, New York, Faulting U.S., Says It Will Pay for Cancer Care for Illegal Immigrants, N.Y. TIMES, Sept. 26, 2007, at B3 ("Federal health officials have told New York State that they will no longer help cover the cost of chemotherapy for illegal immigrants with cancer because it does not qualify under an emergency Medicaid program. But yesterday, state health officials said they would cover all the costs no matter what the federal government does.").

259 Plyler v. Doe, 457 U.S. 202, 230 (1982) (striking down state denial of public primary and secondary education to undocumented children).

260 Julia Preston \& John Cushman, Jr., Obama To Permit Young Migrants To Remain in U.S., N.Y. TIMES, June 16, 2012, at A1.

261 See U.S. CITIZENSHIP \& IMMIGR. SERVICES, supra note 254.

262 Preston \& Cushman, Jr., supra note 260 , at A1. 
was ultimately unsuccessful. ${ }^{263}$ Immigration reformers, in contrast, heralded DACA as bold executive action in the face of legislative inaction, ${ }^{264}$ but a less explored, yet equally important, aspect of the genesis of DACA is the role played by the states. For, in the context of access to education, as with the evolution of the sanctuary city movement, the development of various state laws providing educational benefits to noncitizens without regard to their immigration status provided both a blueprint and an impetus for federal action.

State laws facilitating access to education for documented and undocumented immigrants, and the interactions between the laws of the various states, as well as between the laws of the states and the law and policy of the federal government, in this area of regulation are a key component of the new immigration federalism. Under federal law, access to higher education for noncitizens has long been stringently regulated. ${ }^{265}$ Moreover, under the 1996 immigration and welfare acts, noncitizens' access to a variety of government educational benefits, including loans for undergraduate and graduate studies, is expressly restricted. ${ }^{266}$ Nevertheless, individual states "may provide that an alien who is not lawfully present in the United States is eligible for any State or local public benefit for which such alien would otherwise be ineligible ... through the enactment of a State law after August 22, 1996, which affirmatively provides for such eligibility." 267 In accordance with this provision, a number of states have enacted legislation designed to facilitate immigrant inclusion through access to education.

College attendance is widely perceived as a highly effective means of integrating immigrant youth into their new society 268 - so much so that it has

${ }^{263}$ Crane v. Napolitano, No. 3:12-cv-03247-O, 2013 WL 1744422, at *20 (N.D. Tex. Apr. 23, 2013).

${ }^{264}$ See Deferred Action for Childhood Arrivals (DACA), IMMIGR. EQuALITY, $\mathrm{http}$ ://immigrationequality.org/issues/immigration-basics/daca/ (last visited Sept. 25, 2013).

${ }^{265}$ See, e.g., 8 U.S.C. $\$ 1101(\mathrm{a})(15)(\mathrm{F})(2012)$ (criteria for admission of nonimmigrants on student visas); 8 U.S.C. $\S 1184(\mathrm{~m})$ (limitations on foreign students attending publicly funded institutions, including primary and secondary schooling). The children of undocumented immigrants are, however, granted free access to public primary and secondary schooling. See Plyler v. Doe, 457 U.S. 202, 205, 230 (1982) (invalidating a Texas statute prohibiting free access to public schools for undocumented migrant children and holding that the undocumented status of the children alone failed to establish a sufficient rational basis for denying the benefits that the state afforded to other residents).

266 See Illegal Immigration Reform and Immigrant Responsibility Act of 1996, 8 U.S.C. $\S 1623$ (a) (2012) and Personal Responsibility and Work Opportunity Reconciliation Act of 1996, 8 U.S.C. $\S 1611$ for regulations pertaining to undocumented immigrants and 34 C.F.R. $\S 668.130-139$ (2012) for regulations pertaining to lawfully present migrants. See generally Denise Oas, Immigration and Higher Education: The Debate over In-State Tuition, 79 UMKC L. REV. 877, 877-79 (2011).

2678 U.S.C. $\$ 1621$ (d) ("[s]tate authority to provide for eligibility of illegal aliens for State and local public benefits").

268 See Sandy Baum \& Stella M. Flores, Immigrant Children: Higher Education and Children in Immigrant Families, 21 FUTURE CHILD. 171, 184-86 (2011), available at http://www.princeton.edu/futureofchildren/publications/docs/21_01_FullJournal.pdf. 
for the past decade been the cornerstone of a series of federal "DREAM Act" bills presented to Congress seeking to provide undocumented high school students with a potential path to legal status in the United States. ${ }^{269}$ Most recently, on December 8, 2010 the United States House of Representatives passed H.R. 1751, the Development, Relief, and Education for Alien Minors Act ("DREAM Act"). ${ }^{270}$ The Bill had two components. First, it offered a path to citizenship, as an alternative to deportation, for children who entered the United States without inspection when they were aged fifteen or younger, provided that they were "of good moral character" and either completed two years of a fouryear college degree or served for at least two years in the U.S. military. Second, it provided access to higher education funding, particularly federal student loans, for students who would otherwise qualify apart from their undocumented status. ${ }^{271}$ On December 18, 2010, however, the DREAM Act failed to garner the necessary sixty votes to proceed to a vote on the Senate floor. ${ }^{272}$ The failure of the federal DREAM Act was not unprecedented-since 2001, more than five different iterations of the bill have been introduced unsuccessfully. ${ }^{273}$

In the aftermath of each failed attempt to pass a federal bill, at least one state passed legislation relaxing its own state law restrictions on immigrants' access to state-administered higher education benefits. ${ }^{274}$ Thirteen states-

${ }^{269}$ See American Dream Act, H.R. 1751, 111 th Cong., 1st Sess. $\$ 3$ (2009); American Dream Act, H.R. 1275, 110 th Cong., 1st Sess. $\S 3$ (2007); DREAM Act of 2005, S. 2075, 109 th Cong., 1st Sess. $\S 3$ (2005); DREAM Act, S. 1545, 108th Cong., 1st Sess. $§ 3$ (2003); DREAM Act, S. 1291, 107th Cong., 2d Sess. § 2 (2001).

${ }^{270}$ H.R. 1751; see also Elisha Barron, Recent Development: The Development, Relief, and Education for Alien Minors (DREAM) Act, 48 HARV. J. ON LEGIS. 623, 623-26 (2011).

271 See Barron, supra note 270 , at 623.

272156 CONG. REC. S10, 665-10, 666 (daily ed. Dec. 18, 2010) [hereinafter DREAM Act Cloture Motion Vote] (Roll Call Vote No. 278 Leg.); see also David M. Herszenhorn, Senate Blocks Bill for Young Illegal Immigrants, N.Y. TIMES, Dec. 19, 2010, http:// www.nytimes.com/2010/12/19/us/politics/19immig.html?_r=1\&. The Bill was defeated 5541. See Julia Preston, Immigration Vote Leaves Policy in Disarray, N.Y. TIMES, Dec. 19 , 2010, at 35; Shankar Vedantam, DREAM Act Defeat Reveals Failed Strategy, WASH. PosT, Dec. 19, 2010, at A3.

273 See supra note 269.

${ }^{274}$ See Ann Morse \& Kerry Birnbach, In-State Tuition and Unauthorized Immigrant Students, NAT'L CONF. ST. LEGISLATURES, http://www.ncsl.org/issues-research/immig/instate-tuition-and-unauthorized-immigrants.aspx (last updated Nov. 28, 2012) (These states include: "Texas (HB1403) [in 2001] . . California (AB540), Utah (HB144), and New York (SB7784) in 2001-2002; Washington (HB1079) and Illinois (HB60) in 2003; Kansas (HB2145) in 2004; New Mexico (SB582) in 2005; Nebraska (LB239) in 2006; and Wisconsin (A75) in 2009."). In the aftermath of the failure of the 2010 federal DREAM Act, Illinois and California have recently enacted legislation bearing the same name that provides access to privately funded scholarship funds for in-state immigrant high school graduates, regardless of immigration status. See Illinois DREAM Act S. 2185, 97th Gen. Assemb., Reg. Sess. (Ill. 2011); California DREAM Act, Assemb. 130, 2011 Assemb., Reg. Sess. (Cal. 2011); California Dream Act, Assemb. 131, 2011 Assemb., Reg. Sess. (Cal. 2011). During the same period, Connecticut and Maryland have also, for the first time, enacted legislation providing for in-state tuition for undocumented immigrants. See Morse \& Birnbach, supra. 
California, Connecticut, Illinois, Kansas, Maryland, Nebraska, New Mexico, Oklahoma, New York, Utah, Texas, Washington, and Wisconsin-have enacted legislation providing some form of higher education benefits to immigrants, regardless of immigration status, including in-state tuition, waiver of immigration status reporting at registration, and access to privately funded stateadministered scholarship funds. ${ }^{275}$ California and Texas were the first states to enact legislation allowing all in-state high-school graduates to pay in-state tuition rates in 2001, following the failure of the first federal DREAM Act Bill.276 Shortly thereafter, in 2002, New York and Utah passed similar legislation. ${ }^{277}$ During the 2003 and 2004 legislative sessions, following another failed federal bill, Washington, Oklahoma, Illinois, and Kansas all passed similar laws. ${ }^{278}$ (Oklahoma has since amended its law, leaving granting of instate tuition rates to undocumented students up to the Oklahoma Board of Regents, ${ }^{279}$ which still permits undocumented students who meet Oklahoma's original statutory requirements to receive in-state tuition. $)^{280}$ In 2005 and 2006, once again in the aftermath of a failed federal bill, New Mexico and Nebraska signed undocumented student tuition legislation into law, and Wisconsin enacted a similar law in 2009, but then revoked that law in 2011.281

In May 2011, in the aftermath of the demise of the most recent DREAM Act legislation, Maryland's governor signed a law allowing undocumented students meeting the specified requirements to pay in-state tuition at community colleges. ${ }^{282}$ Two months later, Connecticut enacted a law allowing in-state tuition for undocumented students. ${ }^{283}$ At the same time, Illinois and California each enacted legislation (the Illinois DREAM Act and the California DREAM Act, respectively) providing access to privately funded scholarship funds for in-

275 See Morse \& Bimbach, supra note 274.

276 See CAL. Educ. CODE $\S 68130.5$ (West 2012); Tex. Educ. Code AnN. $\S \S 54.052-$ 54.053 (West 2012).

${ }^{277}$ N.Y. EdUC. LAW $\S \S 355(2)(\mathrm{h})(8), 6206(7)(a)$ (McKinney 2013); UTAH CODE ANN. $\S 53 \mathrm{~B}-8-106$ (LexisNexis 2009).

278 WASH. REV. CODE $§ 28$ B.15.012(2)(e) (2012); OKLA. STAT. tit. 70, $§ 3242(\mathrm{~B})(2)$ (2011); 110 ILl. COMP. STAT. 305/7e-5(a)(5), 520/8d-5(a)(5) (2012); KAN. STAT. ANN. § 76$731 \mathrm{a}(\mathrm{b})(2)(\mathrm{C})(2012)$.

279 OKLA. STAT. tit. $70, \S 3242(B)(2)$.

280 Id.

281 Neb. REv. STAT. ANN. §85-502 (LexisNexis 2012); N.M. STAT. ANN. § 21-1-4.6(B) (2005); WIS. STAT. $\$ 36.27(2)(a)(6)$ (2012) (allowing length-of-time-in-state requirements to be met by intermittent work in the state). Nebraska has the strictest rule.

282 S. 167, 2011 Gen. Assemb., Reg. Sess. (Md. 2011). Opponents of the law subsequently petitioned to suspend the law's implementation and it appeared as a referendum on the 2012 ballot. See Editorial, In Maryland, a Referendum on a Dream, WASH. Post, July 15, 2011, at A6; Nick Anderson \& Luz Lazo, Md. Voters Approve "Dream Act" Law, WASH. POST, Nov. 6, 2012; http://articles.washingtonpost.com/2012-11 06/local/35506258_1_tuition-discount-college-students-neil-c-parrott (last updated Nov. 7, 2012 12:23 AM) (discussing the results of the referendum).

${ }^{283}$ See S. 40, 2011 Gen. Assemb., Jan. Sess. (Conn. 2011). 
state immigrant high school graduates, regardless of immigration status. ${ }^{284}$ During the 2011 legislative session, legislators in at least ten other statesArizona, Colorado, Florida, Iowa, Massachusetts, Mississippi, Missouri, New Jersey, Oregon, and Rhode Island-introduced nineteen further bills that would allow undocumented students to receive in-state tuition rates. ${ }^{285}$ The opportunity that exists in the post-Arizona "new" immigration federalism for states to engage in immigrant-inclusionary education-related rulemaking is thus hardly a "new" development. But it is nonetheless striking that in the first six months of 2013 alone, so-called "State DREAM Acts," were introduced in sixteen further states, and proposals for greater access to scholarships and/or financial aid for immigrant students were considered in several states. ${ }^{286}$ The resurgence of such laws in recent months further supports the argument that immigrant-inclusionary rulemaking will define the parameters of the new direction for immigration federalism in the post-Arizona legal landscape.

Indeed, legal challenges to legislation permitting undocumented immigrants to pay in-state tuition rates have, in common with challenges to sanctuary ordinances, thus far proven unsuccessful. In Martinez $v$. Regents of the University of California, ${ }^{287}$ for example, the California Supreme Court ruled that the California Educational Code provisions governing in-state tuition, as amended by the California DREAM Act, ${ }^{288}$ were not preempted by federal law. The Court reasoned that the State of California had opted to permit undocumented immigrants to pay in-state tuition rates based on their fulfillment of a number of distinct criteria (namely a California high school diploma, attendance at a California high school for three or more years, and the filing of an affidavit attesting that they intended to attempt to legalize their immigration status) rather than being predicated on residency in the state, and thus the Californian legislation did not conflict with the federal scheme. ${ }^{289}$ The United States Supreme Court subsequently denied Martinez's petition for certiorari. ${ }^{290}$

${ }^{284}$ See Illinois DREAM Act S. 2185, 97th Gen. Assemb., Reg. Sess. (Ill. 2011); California DREAM Act, Assemb. 130, 2011 Assemb., Reg. Sess. (Cal. 2011); California Dream Act, Assemb. 131, 2011 Assemb., Reg. Sess. (Cal. 2011).

285 Morse \& Birnbach, supra note 274 . This is not to suggest that all states are in favor of DREAM legislation. Two states, Alabama and South Carolina, prohibit undocumented students from enrolling in public postsecondary institutions and four states, Arizona, Colorado, Georgia, and Indiana, expressly prohibit undocumented students from receiving in-state tuition rates. See id; see also Michael A. Olivas, The Political Economy of the Dream Act and the Legislative Process, 55 WAYNE L. REV. 1757, 1769-84 (2009).

286 See NAT'L IMMIGRATION LAW CTR., supra note 11, at 6-10.

${ }^{287}$ Martinez v. Regents of the Univ. of Cal., 241 P.3d 855, 870 (Cal. 2010), cert. denied, 131 S. Ct. 2961 (2011).

${ }^{288}$ CAL. EDUC. CODE $\S 68130.5$ (West 2012).

${ }^{289}$ Martinez, 241 P.3d at 864 . For a comprehensive discussion of the court's ruling, see Hing, supra note 246 , at 291-97.

${ }^{290}$ Martinez v. Regents of the Univ. of Cal., 241 P.3d 855 (Cal. 2010), cert. denied, 131 S. Ct. 2961 (2011). 
As with the evolution of the sanctuary movement, the development of these various state laws providing educational benefits to noncitizens without regard to their immigration status hints at the potential "hydraulics" of immigration regulation reform. On each occasion that the federal government failed to pass a DREAM Act, state legislatures introduced their own measures. ${ }^{291}$ With the publication of the DACA memorandum, drawing upon the successes of the state schemes, the "hydraulics" of rulemaking pertaining to undocumented immigrants' access to education, which had hitherto been visible only in the context of "vertical" or "federal-state" reactions and relationships, also became evident in the "horizontal" federalism context. Now, as lawmakers and advocates are releasing suggestions for comprehensive immigration reform, every single proposal, including Senate Bill S.744 and the White House's "Blueprint for Immigration Reform" 292 involves guaranteeing immigrant youth improved access to education and educational funding. This latest development underscores the dynamism of the new immigration federalism, wherein state legislation intended to foster immigrant inclusion may stand alone, may overlap, or may serve as an inspiration for or a spur to action by other states or by the federal government. 293

\section{Conclusion: The Challenges AND Opportunities of the NeW IMMIGRATION FEDERALISM}

The Supreme Court's recent rulings in Arizona v. United States and Chamber of Commerce $v$. Whiting portend a new era of immigration federalism,

291 See supra notes 273-85 and accompanying text.

292 See THE WhITE HouSE, BUILDING A 21 ST CENTURY IMMIGRATION SYSTEM 25 (2011) available at http://www.whitehouse.gov/sites/default/files/rss_viewer/immigration_blue print.pdf.

${ }^{293}$ Indeed, sanctuary ordinances and access to education initiatives are, of course, far from the only areas in which the federal government's failure to act to foster the inclusion of immigrants into their local polity has resulted in supplementary, or even conflicting, local rulemaking. States and localities have, for example, promulgated immigrant-inclusionary laws in response to a variety of restrictive federal regulations in areas as diverse as medical care, see Kershaw, supra note 258, at B3 ("Federal health officials have told New York State that they will no longer help cover the cost of chemotherapy for illegal immigrants with cancer because it does not qualify under an emergency Medicaid program. But yesterday, state health officials said they would cover all the costs no matter what the federal government does."), workers' rights, see Peter Romer-Friedman, Eliot Spitzer Meets Mother Jones: How State Attorneys General Can Enforce State Wage and Hour Laws, 39 ColuM. J.L. \& SOC. PROBS. 495, 540 (2006) (describing Spitzer's intervention where state courts "had held that federal immigration law preempts undocumented workers from receiving lost earning recoveries based on wages earned domestically in common-law tort and state statutory worker-safety actions"), insurance, see Miriam Jordan, Illegal Residents Get Legal Route to Car Coverage, WALL ST. J., May 1, 2007, at A1, and welfare benefits, see Peter J. Spiro, Federalism and Immigration: Models and Trends, 167 INT'L SOC. SCI. J. 67, 71-72 (2001) (noting that most states responded to the Personal Responsibility and Work Opportunity Reconciliation Act "with generous eligibility criteria for aliens"). 
defined not by state and local efforts to enforce immigration laws and deport immigrants, but rather by state and local experimentation with measures intended to foster immigrant inclusion. This new framework, which involves the redirection and reorientation of existing rulemaking pertaining to immigrants and immigration as well as the development of novel schemes, has tremendous potential to inform the growing national debate about comprehensive immigration reform. In his State of the Union Address on February 12, 2013, President Obama urged Congress to "get it done," declaring that if lawmakers could send him a comprehensive immigration reform bill in the next few months he would "sign it right away."294 On June 27, 2013, the Senate Immigration Reform Bill passed with a strong majority (68-32). ${ }^{295}$ Now, as House legislators get to work they would do well to consider the challenges and opportunities for meaningful action at the federal, state, and local levels.

The new direction for immigration federalism in the aftermath of Arizona and Whiting unquestionably poses both challenges and opportunities for federal and state executives, legislators, and jurists. During the next legislative session, Congress and many state legislatures will undoubtedly consider a range of immigrant-inclusionary and immigrant-exclusionary bills. At the same time, the lower federal courts in Arizona, Utah, Indiana, Georgia, and South Carolina will likely rule on the motions pending before them pertaining to the state independent enforcement statutes. It is also possible that additional lawsuits will be pursued during this period opposing the Illinois and California sanctuary ordinances or the Obama Administration's DACA program. As this Article has attempted to demonstrate, this dynamism and fluidity is an inevitable consequence of the new immigration federalism.

A significant challenge that courts and state legislatures face in the wake of Arizona v. United States is in interpreting the Supreme Court's ruling with respect to Section 2(B) of S.B. 1070, the "show me your papers" provision of the Arizona Act, which the Court acknowledged could be subject to nonfrivolous as-applied equal protection challenges. ${ }^{296}$ Indeed, after the opinion issued, a number of high-profile individuals, including President Obama, Attorney General Eric Holder, and former Arizona Attorneys General Grant

${ }^{294}$ President Barack Obama, Remarks by the President in the State of the Union Address (Feb. 12, 2013) (transcript available at http://www.whitehouse.gov/the-pressoffice/2013/02/12/remarks-president-state-union-address).

295 Ashley Parker \& Jonathan Martin, Senate, 68 to 32, Passes Overhaul for Immigration, N.Y. TIMES, June 28, 2013, at A1.

${ }^{296}$ Arizona v. United States, 132 S. Ct. 2492, 2509 (2012). The specter of racial profiling loomed large during the Arizona suit, although for the purposes of its facial challenge to S.B. 1070 the United States explicitly declined to pursue any legal claims based on racial profiling and the Court therefore did not consider equal protection concerns in its opinion. During oral argument, for example, Solicitor General Verrilli engaged in an extended colloquy with the Justices about racial profiling, while asserting repeatedly "we are not making an allegation of racial profiling." Transcript of Oral Argument at 46, Arizona, 132 S. Ct. 2492 (No. 11-182), available at http://www.supremecourt.gov/oral_arguments/ argument_transcripts/11-182.pdf. 
Woods and Terry Goddard, issued statements expressing their concern that the implementation of Section 2(B) might lead to racial profiling. ${ }^{297}$ As the Arizona litigation proceeds beyond the preliminary injunction and state officers begin to exercise their S.B. 1070 Section 2(B) powers, allegations of racial profiling may come to the fore. Such allegations, if proven true, would demonstrate that state law enforcement personnel's exercise of their S.B. 1070 Section 2(B) powers was incompatible with both the Equal Protection Clause of the Fourteenth Amendment to the United States Constitution and the theory of state action underpinning the new immigration federalism. State action in the immigration arena is now limited to actions that neither conflict with federal enforcement priorities nor contravene fundamental constitutional rights.

Arizona's example will soon be followed in other jurisdictions. Federal courts in Utah, Indiana, Georgia, and South Carolina are poised, like Alabama, to follow the Supreme Court's Arizona precedent and to allow those states' "show me your papers" provisions to be implemented. Other states, notably Wisconsin, Illinois, Michigan, Pennsylvania, and Ohio, where S.B. 1070-style laws are currently pending, 298 are contemplating laws modeled directly on S.B. 1070 Section 2(B), or laws designed to test the boundaries of the Court's Arizona holding. In each jurisdiction that adopts Section 2(B) style provisions, state and local officers will necessarily become involved in making immigration status inquiries and determinations, leaving states and localities susceptible to claims of racial discrimination, which is incompatible with the new framework of immigration federalism. The challenge for state legislators, going forward, is thus to determine whether the additional expenditure of personnel and resources required by such laws, including the costs of training officers to avoid claims of impermissible racial profiling, combined with the cost of litigating any challenges to the implementation of such laws, is worthwhile. Federal and state courts reviewing such cases will be called upon to distinguish between state officers" "permissible" and "impermissible" consideration of race as a factor

${ }^{297}$ See Press Release, President Barack Obama, Statement on the United States Supreme Court Ruling on Arizona's Illegal Immigrant Enforcement Legislation (June 25, 2012), http://www.whitehouse.gov/the-press-office/2012/06/25/statement-president-supreme-courts-ruling-arizona-v-united-states ("I remain concerned about the practical impact of the remaining provision of the Arizona law that requires local law enforcement officials to check the immigration status of anyone they even suspect to be here illegally.... Going forward, we must ensure that Arizona law enforcement officials do not enforce this law in a manner that undermines the civil rights of Americans. . .."); see also Press Release, Dep't of Justice, Statement of Attorney General Eric Holder on the Supreme Court's Ruling on Arizona $v$. The United States (June 25, 2012), http://www.justice.gov/opa/pr/2012/June/12ag-801.html ("I remain concerned about the impact of Section 2.... As the Court itself recognized, Section 2 is not a license to engage in racial profiling. ..."); Former Arizona Attorneys General React to Arizona Supreme Court Ruling, NAT'L IMMIGR. F. (June 26, 2012), http://immigrationforum.org/media/former-arizona-attorneys-general-react-toarizona-supreme-court-ruling (statement of Grant Woods) ("The remaining portions of SB 1070 will in all likelihood lead to racial profiling.").

${ }^{298}$ See SB 1070 Copycats, supra note 139. 
under federal and state law. Given the Supreme Court's clear guidance in Arizona and Whiting about the permissible boundaries of state immigrationrelated action within the new framework of immigration federalism, the future of any such "copy-cat" laws will likely be short-lived.

At the same time, federal immigrant-inclusionary developments in 20122013, such as the launch of DACA, and the Justice Department's policy of "prioritized enforcement," which were influenced by state DREAM Acts and the sanctuary movement, suggest that now, more than ever, the states have an opportunity to be "laboratories of democracy" for immigrant-inclusionary rulemaking. The flurry of immigrant-inclusionary lawmaking by state legislatures in the first six months of 2013 suggests that (at least some) states have embraced this opportunity to pursue immigrant-inclusive policies that may serve as models for future federal rulemaking. The influence that this state action has had upon the current debate about comprehensive immigration reform should not be underestimated - almost all of the suggestions for reform currently under consideration have been advocated and/or attempted at the state level. The Arizona Court may have reaffirmed the federal government's "broad, undoubted power over the subject of immigration and the status of aliens,"299 and its wide-ranging discretion to pursue (or not pursue) prosecutions for various immigration violations, but in so doing it has also created a landscape within which there is a fresh opportunity for immigrant-inclusionary rulemaking to flourish.

A challenge now for the federal government is to determine the extent to which it wishes to engage formally with the different iterations of state rulemaking pertaining to immigrants. The Department of Homeland Security's decision to sever its Section $287(\mathrm{~g})$ agreements with Arizona ${ }^{300}$ suggests that it is unwilling to condone any immigrant-exclusionary state action that does not comport with its own priorities. At the same time, the Department of Justice Inspector General's finding that the New York, San Francisco, and Oregon sanctuary policies do not violate federal law hints at a possible acceptance of immigrant-inclusionary state or local noncooperation policies. ${ }^{301}$

Within the post-Arizona, post-Whiting framework of immigration federalism, the challenge for the state and local proponents of such immigrantinclusionary policies, particularly comprehensive sanctuary ordinances, is to ensure that the underlying rationale is to serve a legitimate state or local purpose, not to regulate immigration. ${ }^{302}$ As cities like Chicago, and states such as California, attempt to formulate and justify laws and policies designed to further immigrant inclusion, they must ensure that their goal is not to intrude upon the "extensive and complex" 303 federal scheme of immigration regulation,

299 Arizona, 132 S. Ct. at 2498.

${ }^{300}$ See discussion supra, Parts IV.A-C.

${ }^{301}$ See discussion supra, Part V.A.

302 See discussion supra, Part V.A.

${ }^{303}$ Arizona, 132 S. Ct. at 2495. 
but rather to legitimately apportion their own personnel and fiscal resources in orthogonal areas of state law.

In these (and doubtless other) ways, the new immigration federalism will have a profound effect on the legislative and jurisprudential landscape of the United States. Arizona v. United States, Chamber of Commerce v. Whiting, and their inevitable progeny will reshape immigration and alienage jurisprudence, curbing state and local action to exclude immigrants, particularly through independent direct and independent enforcement legislation, while continuing to allow state and local regulations designed to foster the inclusion of immigrant groups. Just how exactly these thoroughgoing changes at the national, state, and local level will influence long-awaited congressional comprehensive immigration reform remains to be seen, ${ }^{304}$ but irrespective of how (or indeed whether) Congress ultimately chooses to act, this fundamental change has already begun.

${ }^{304}$ See John D. Skrentny \& Micah Gell-Redman, Comprehensive Immigration Reform and the Dynamics of Statutory Entrenchment, 120 YALE L.J. ONLINE 325, 332-33 (2011), http://www.yalelawjournal.org/the-yale-law-journal-pocket-part/legislation/comprehensiveimmigration-reform-and-the-dynamics-of-statutory-entrenchment/. 